Review

\title{
Piperine-A Major Principle of Black Pepper: A Review of Its Bioactivity and Studies
}

\author{
Zorica Stojanović-Radić ${ }^{1, *}$, Milica Pejčić ${ }^{1}$, Marina Dimitrijević ${ }^{1}$, Ana Aleksić ${ }^{1}$, \\ Nanjangud V. Anil Kumar ${ }^{2}\left(\mathbb{D}\right.$, Bahare Salehi ${ }^{3, * \mathbb{D}}$, William C. Cho ${ }^{4, * \mathbb{B}}$ and \\ Javad Sharifi-Rad ${ }^{5, *}$ (1) \\ 1 Department of Biology and Ecology, Faculty of Sciences and Mathematics, University of Niš, Višegradska 33, \\ 18000 Niš, Serbia; milicapejcic1991@gmail.com (M.P.); dimitrijevicmarina92@yahoo.com (M.D.); \\ 90anna.aleksic@gmail.com (A.A.) \\ 2 Department of Chemistry, Manipal Institute of Technology, Manipal Academy of Higher Education, \\ Manipal, 576104, India; nv.anil@manipal.edu \\ 3 Student Research Committee, School of Medicine, Bam University of Medical Sciences, Bam 44340847, Iran \\ Department of Clinical Oncology, Queen Elizabeth Hospital, Hong Kong, China \\ 5 Department of Pharmacology, Faculty of Medicine, Jiroft University of Medical Sciences, \\ Jiroft 7861756447, Iran \\ * Correspondence: zstojanovic@pmf.ni.ac.rs (Z.S.-R.); bahar.salehi007@gmail.com (B.S.); \\ williamcscho@gmail.com (W.C.C.); javad.sharifirad@gmail.com (J.S.-R.)
}

Received: 30 August 2019; Accepted: 21 September 2019; Published: 12 October 2019

Featured Application: The data presented by this review article, which summarizes all bioactivity data of piperine together with results of human clinical trials, provide a strong base for development of future drugs that would act as preventive agents and/or would enhance the activities of other drugs.

\begin{abstract}
Piperine is the main compound present in black pepper, and is the carrier of its specific pungent taste, which is responsible for centuries of human dietary utilization and worldwide popularity as a food ingredient. Along with the application as a food ingredient and food preservative, it is used in traditional medicine for many purposes, which has in most cases been justified by modern scientific studies on its biological effects. It has been confirmed that piperine has many bioactive effects, such as antimicrobial action, as well as many physiological effects that can contribute to general human health, including immunomodulatory, hepatoprotective, antioxidant, antimetastatic, antitumor, and many other activities. Clinical studies demonstrated remarkable antioxidant, antitumor, and drug availability-enhancing characteristics of this compound, together with immunomodulatory potential. All these facts point to the therapeutic potential of piperine and the need to incorporate this compound into general health-enhancing medical formulations, as well as into those that would be used as adjunctive therapy in order to enhance the bioavailability of various (chemo)therapeutic drugs.
\end{abstract}

Keywords: piperine; bioactivity; clinical studies; bioavailability of drugs

\section{Introduction}

Piperine is a compound belonging to the alkaloids; it is responsible for the pungent taste of various pepper species, and has, in addition to being found in the members of the Piperaceae family, been detected in several other plant species (Rhododendron faurie, Vicoa indica, Anethum sowa, and others) [1]. The amount of piperine is highest in Piper nigrum L., and varies from $2 \%$ to as high as 9\% [2], depending on environmental factors such as climate and/or place of origin, as well as growing conditions. Black pepper (Piper nigrum L.) is the most used among the pepper species, and along with its worldwide 
utilization as a spice, it is known as an important medicinal plant. Its traditional use can be traced to thousands of years ago, due to its unique role in Ayurvedic medicine, where it represents one of the components of "tricatu" (equal proportions of black pepper, long pepper and ginger) [3]. Tricatu or its individual compounds are the base for 210 out of 370 formulations listed in the Handbook of Domestic Medicines and Common Ayurvedic Remedies. Pepper is traditionally recommended for fevers and a variety of gastrointestinal conditions, as well as for neurological and broncho-pulmonary disorders (asthma and chronic bronchitis) [3]. Traditional medicine, such as Chinese medicine, utilizes black pepper for the treatment of various pains (headaches, muscular pain), rheumatism, infections such as strep throat and influenza, as well as for enhancing the blood circulation [2]. Pepper contains fibers, starch, proteins, carbohydrates, lignans, alkaloids, flavonoids, phenols, amides and essential oil. The compounds that are found in black pepper essential oil, which is present in a content of up to $3.5 \%$ in the fruits, give it a specific aroma and taste [4]. The major compounds found in this essential oil are sabinene, $\alpha$-pinene and $\beta$-pinene, $\beta$-caryophyllene, phellandrene, limonene, linalool, citral and others. Among other compounds, antioxidants such as beta carotene, lauric, myristic and palmitic acids, as well as piperine, are found in pepper [4]. The pungent taste of pepper and its many pharmacological properties are attributed to piperine (piperoylpiperidine, $\mathrm{C}_{17} \mathrm{H}_{19} \mathrm{NO}_{3}$ ), one of its major alkaloids. Investigations on piperine bioactivities have reported the very high spectrum of physiological effects, including antihypertensive, antiaggregant, antioxidant, antitumor, antispasmodic, antiasthmatic, antidepressant, anxiolytic, and many others [5]. Along with an array of biological activities, piperine is known for its ability to increase the bioavailability of drugs, and thus enhance their therapeutic potential $[1,6,7]$. Along with beneficial effects, piperine has, as the main ingredient of the most known spice, pepper, been traditionally used as a food for centuries, and does not present any threat upon human consumption. Additional studies have revealed the safety of its consumption by reporting a lack of piperine genotoxicity in Ames tests and in micronucleus tests [8]. This review encompasses the available literature data on the various biological activities of piperine, as well as the results of clinical studies performed on humans.

\section{Pharmacology of Piperine: In Vitro and In Vivo Studies}

\subsection{Immunomodulatory and Anti-Allergic Effect}

The immunomodulatory potential of piperine have demonstrated promising potential. Bezerra et al. [9] reported that the incubation of tumor cell lines with 5-fluorouracil (5-FU) in the presence of piperine produced an increase in growth inhibition, observed by lower $\mathrm{IC}_{50}$ values for 5 -FU. At the same time, leucopoenia induced by treatment with 5-FU was reduced by the combined use with piperine, showing improved immunocompetence hampered by 5-FU [9]. In the study of Bernardo et al. [10], which evaluated the effect of piperine to $B$ cell functioning and on the humoral immune response to T-un/dependent antigens, it was found that, in vitro, it inhibits proliferative response induced by lipopolysaccharide (LPS) and immunoglobulin $\alpha$-IgM antibody. Also, piperine resulted in inhibition of IgM antibody secretion and reduced expression of cluster of differentiation CD86 [10]. A recent study of Lee et al. demonstrated that piperine in combination with gamma-aminobutyric acid (GABA) mediated p38 and JNK MAPK activation, which increased EPO and EPO-R expression, resulting in up-regulation of IL-10 and NF-kB [11].

In addition to immunomodulation, piperine exhibits significant anti-allergic activity in ovalbumin-induced allergic rhinitis in mice. Piperine significantly ameliorated sneezing, rubbing, and redness induced by sensitization of nerve endings resulted from histamine released in response to antigen-antibody reaction [12], but also decreased nitric oxide (NO) levels due to lower migration of eosinophils into nasal epithelial tissue. As in the histopathological section of the nasal mucosa, it was found that piperine treatment attenuated inflammation, redness, and disruption of alveoli and bronchiole [12]. In an ovalbumin-induced asthma model, the administration of piperine decreased the 
infiltration of eosinophils and reduced airway hyperresponsiveness by suppressing $\mathrm{T}$ cell activity and Th2 cytokine production [13].

\subsection{Anti-Diabetic Effect}

Piperine enhances hepatic oxidized glutathione (GSSG, by 100\%) and decreases renal glutathione (GSH, by 35\%) concentration and renal glutathione reductase (GR) activity (by 25\%) in streptozotocin-induced diabetic rats when compared to healthy controls [14]. Brahmanaidu et al. [15] reported that piperine would suppress the body weight, and improve insulin and leptin sensitivity, thereby regulating obesity. In the study of twenty piperine derivatives containing benzothiazole moiety, nine piperine analogs exhibited higher anti-diabetic activity, in comparison with the standard, rosiglitazone [16]. Piperine exhibits anti-hyperglycemic activity in alloxan-induced diabetic mice since significant blood glucose-lowering effect was registered after 14 days of oral intake at a dose of $20 \mathrm{mg} / \mathrm{kg}$. On the other hand, the same study showed that high dose $(40 \mathrm{mg} / \mathrm{kg})$ acutely raise blood glucose level [17]. Another confirmation of piperine's ability to increase the efficacy of various drugs was demonstrated with respect to those used to treat diabetes. In another study, on alloxan-induced diabetic rats, the combination of piperine with a therapeutic dose of metformin $(10 \mathrm{mg} / \mathrm{kg}+250 \mathrm{mg} / \mathrm{kg})$ showed a significantly higher lowering of blood glucose level as compared to metformin alone on both the 14th and 28th day [18]. On streptozotocin-induced diabetic rats, the combination of piperine and glimepiride increased all the pharmacokinetic parameters (Cmax, AUC0-n, AUCtotal, $\mathrm{T}_{1 / 2}, \mathrm{MRT}$, and decreased the clearance, $\mathrm{Vd}$ ) and improved overall antioxidant status [19]. Piperine reduces ligand-induced liver $\mathrm{X}$ receptor $\alpha$ activity in a dose-dependent manner, showing its role as its antagonist, while its dietary effects in high-fat-diet (HFD, $+0.05 \%$ piperine) rats showed decreased plasma insulin and glucose concentrations and increased insulin sensitivity [20]. Consequently, it downregulates genes involved in endoplasmic reticulum stress and upregulates GLUT2. Piperine inhibits the adipocyte differentiation of 3T3-L1 cells by decreasing master adipogenic transcriptional factors PPAR $\gamma$, SREBP-1c, and C/EBP $\beta$, leading to inhibition of adipogenesis [21]. It was reported that piperine inhibits uridine diphosphate-glucose dehydrogenase (UDP-GDH), UDP-glucuronosyltransferase (UDP-GT) and decreases UDP-glucuronic acid (UDPGA) in rat and guinea pig liver and intestine [22].

Piperine reduces total plasma cholesterol, low density lipoprotein (LDL) cholesterol, very low-density lipoprotein (VLDL), the activity of 3-hydroxy 3-methyl glutaryl coenzyme A (HMG $\mathrm{CoA}$ ) reductase in the tissues, and increases lipoprotein lipase (LPL) and plasma lecithin cholesterol acyl transferase (LCAT). All these effects consequently result with the prevention of the plasma lipids and lipoproteins accumulation in antithyroid drug-induced hypercholesterolemic rats [23].

\subsection{Anti-Inflammatory Effect}

Piperine decreases liver marker enzymes activity (aspartate transaminase (AST), alanine, transaminase (ALT), and alkaline phosphatase (ALP)) in acetaminophen-challenged mice, indicating its hepatoprotective and antioxidant effects [24]. Piperine decreases blood urea nitrogen (BUN), creatinine, and malondialdehyde (MDA), and increases superoxide dismutase (SOD), glutathione peroxidase (GPx) in the kidney of lead acetate-treated nephrotoxic rats [25]. Similar results were observed in cadmium-induced oxidative stress in cultured human peripheral blood lymphocytes in a HFD [26] and antithyroid drug-induced hyperlipidemic rats [27]. These enzymatic studies also revealed the anti-inflammatory activity of piperine. The administration of piperine to rats before irradiation significantly abolished the radiation-induced alleviation in lungs catalase (CAT) and GPx activities, reduced GSH content and significantly limited the elevation in serum tumor necrosis factor- $\alpha$ (TNF- $\alpha$ ), interleukin-1 $\beta$ (IL-1 $\beta$ ) and interleukin-6 (IL-6) levels, which demonstrated its protective function from x-rays [28]. Piperine inhibits LPS-induced expression interferon regulatory factor (IRF)- 1 and IRF-7 mRNA, phosphorylation of IRF-3, type 1 IFN mRNA, and reduces the activation of signal transducer and activator of transcription (STAT)-1. The results indicate that piperine is a potential molecule for treating lipopolysaccharide-induced inflammation [29]. Similarly, Wang-Sheng et al. [30] reported 
that piperine inhibits LPS-induced TNF- $\alpha$, IL-6, IL-1 $\beta$, and prostaglandin E2 (PGE-2) production in BV2 microglial cells. In the human peripheral blood mononuclear cells (PBMCs), piperine was found to inhibit IL-2 and interferon gamma (IFN-x) [31]. Piperine inhibits the production of PGE2 and NO induced by LPS while decreasing TNF- $\alpha$, inducible NO synthase (iNOS) and cyclooxigenase- 2 (COX-2) in RAW264.7 cells, resulting in anti-inflammatory activity [32]. In the model of LPS-induced inflammation of nucleus pulposus cells, piperine inhibited IL-1 $\beta$, TNF- $\alpha$, IL-6, expression of iNOS, activities of matrix metalloproteinases MMP-3 and MMP-13, ADAMTS-4 mRNA, and ADAMTS-5 mRNA [33].

In an arthritis animal model, at doses of 10 and $100 \mu \mathrm{g} / \mathrm{mL}$, piperine inhibits the IL-6, MMP-13, activator protein 1 (AP-1) and reduces PGE2 in a dose-dependent manner, and significantly reduced nociceptive and arthritic symptoms in piperine-treated rats. Histological investigation revealed reduced inflammatory area in the ankle joints [34]. Piperine downregulates IL-1, MMP-8, and MMP-13 in periodontitis, leading to protective effects on inflammation, alveolar bone loss, bone microstructures, and collagen fiber degradation in experimental periodontitis [35]. Son et al. [36] reported that piperine suppresses cytosolic phospholipase A2 (cPLA2) and inhibits thromboxane A2(TXA2) synthase, but not of COX-1, in collagen-stimulated platelets. It also inhibits the lipopolysaccharide-induced generation of PGE2 and PGD2 in RAW264.7 cells by suppressing the activity of COX-2, without effect on cPLA2 [36]. Piperine reduces proinflammatory cytokines IL-1 $\beta$, IL- 6 and TNF- $\alpha$, COX-2, nitric oxide synthase (NOS-2), and nuclear factor kappa B (NF- $\mathrm{KB}$ ) in the cerebral ischemia-reperfusion-induced inflammation rat model [34].

In one study, performed on rats, piperine was found to reduces SOD, CAT, GPx, and GR, and increases hydrogen peroxide generation and lipid peroxidation in the epididymis, thus having a negative effect to redox state and affecting fertility [37].

\subsection{Effect of Piperine to the Gastrointestinal Tract}

During investigation of whether the bioavailability enhancement potential of piperine is related to the delay in transit time of solids and liquids, and therefore to a prolonged exposure of drugs to the absorptive surface area of GI tract, piperine was found to inhibit gastric emptying and gastrointestinal transit in rats and mice [38]. In the study, in which piperine $(20$ and $30 \mathrm{mg} / \mathrm{kg}$, i.p.) and indomethacin $(10 \mathrm{mg} / \mathrm{kg}$, orally) were administered to mice, there was a dose-dependent decrease in the ulcer index in the mice treated with both doses of piperine [39]. In another experimental model of gastric ulcer, piperine in doses of 25, 50 and $100 \mathrm{mg} / \mathrm{kg}$ protected against gastric ulceration induced by stress (inhibitory rates from 16.9-48.3\%), indometacin (4.4-64.4\%), $\mathrm{HCl}(19.2-59.6 \%)$, and pyloric ligation $(4.8-26.2 \%)$ in rats or mice [40].

\subsection{Antimutagenic and Cancer-Preventive Effect of Piperine}

Piperine was found to possess antimutagenic potential since it inhibits the mutagenicity of the three food mutagens (3-Amino-1-methyl-5H-pyrido[4,3-b]indole (Trp-P-2), 2-Amino-3-methylimidazo [4,5-f]quinoline (IQ) and 2-amino-3,8-dimethylimidazo[4,5-f]quinoxaline (MelQx)) [41]. At a dose of $100 \mathrm{mg} / \mathrm{kg}$, piperine gave a statistically significant reduction in cyclophosphamide-induced chromosomal aberrations in rat bone marrow cells [42]. Hepatic and renal cadmium levels were significantly decreased in mice when treated with piperine, demonstrating its protective action to this type of renal and hepatic toxicity [43]. When orally administered for three days prior the treatment with mitomycin C, piperine inhibited the frequency of sister chromatid exchanges (up to $41.82 \%$ ), as well as the number of chromosomal aberrations in mouse splenocytes and spermatocytes $(50 \%$ and $40.78 \%$ of inhibition, respectively) [44]. Another study found that piperine inhibits aflatoxin B1-induced cytotoxicity and genotoxicity in V79 Chinese hamster cells [45]. The results of Kumar et al.'s [46] in vitro experiments on deltamethrin (DLM, a pyrethroid insecticide, and a potent immunotoxicant)-induced thymic apoptosis in primary murine thymocytes demonstrated the protective role of piperine $(1,10$ and $50 \mu \mathrm{g} / \mathrm{mL}$ ). Its administration led to increased cell viability in a concentration-dependent manner 
and reduced levels of early activated markers of apoptosis (reactive oxygen species and caspase-3), as well as GSH depletion, all induced by DLM.

\subsection{Anti-Cancer Effect of Piperine}

In vitro studies on various cancer cells showed that piperine possesses cytotoxic action (selective toward tumor cells) against several types of cancer, including breast, lung, prostate, cervical, and other cancers.

\subsubsection{Breast Cancer}

The study on HER2 overexpressing breast cancer cells demonstrated inhibited proliferation and induced apoptosis by activating caspase-3 and cleavage of PARP [47]. Moreover, it was determined that piperine inhibits HER2 gene expression at the transcriptional level and enhances sensitization of HER2 overexpressing cells to paclitaxel killing. The same study found that it inhibits AP- 1 and NF- $\mathrm{KB}$ activation, blocks extracellular signal-regulated kinase (ERK1/2), p38 mitogen-activated protein kinase (p38 MAPK), and Akt signaling pathways, and suppresses epidermal growthy factor (EGF)-induced MMP-9 expression [47]. Without affecting normal mammary epithelial cell growth, piperine inhibits the in vitro growth of triple-negative breast cancer cells (TNBC), and hormone-dependent breast cancer cells. Also, it increases the expression of p21(Waf1/Cip1) and inhibits survival-promoting Akt activation [48], inhibits mammosphere formation, breast stem cell marker aldehyde dehydrogenase (ALDH), and Wnt signaling pathway without causing toxicity to differentiated cells [49]. In another study, on TNBC cells, the efficacy of factor-related apoptosis-inducing ligand (TRAIL)-based therapy has been enhanced when piperine was added as an adjuvant [50]. In a model of 4T1 murine breast cancer cells, injection of piperine into tumors (35-280 $\mu \mathrm{mol} / \mathrm{L})$ inhibited the growth of $4 \mathrm{~T} 1$ cells in a time- and dose-dependent manner, and decreased the expression of MMP-9 and MMP-13 [51]. It has been reported that piperine analogs, formed by replacing the piperidine nucleus with different amino acids and substituted aniline, exhibit significantly enhanced activity against human breast cancer cells [52]. The best cytotoxic activity $\left(\mathrm{IC}_{50}-0.74 \mu \mathrm{mol}\right.$ ) was obtained by a histidine analog of piperine containing imidazole ring structure.

\subsubsection{Lung Cancer}

A set of studies investigated the effect of piperine on lung cancer and found very promising results. Lin et al. [53] found that piperine showed selective cytotoxicity toward lung cancer cell line (A549) by inducing apoptosis through arresting $\mathrm{G} 2 / \mathrm{M}$ phase of the cell cycle and activating caspase- 3 and caspase- 9 cascades in cancer cells. It also decreased Bcl-2 protein expression and increased Bax protein, leading to higher Bax/Bcl-2 ratio. Benzo(a)pyrene induces lung carcinogenesis, by decreasing glutathione transferase (GST), quinone reductase (QR) and UDP-GT and increasing the hydrogen peroxide level. In the study on Swiss albino mice, piperine $(50 \mathrm{mg} / \mathrm{kg} \mathrm{b.wt}$.) was orally given to mice together with benzo(a)pyrene $(\mathrm{BaP})$ for 16 weeks. In animals treated with piperine, reduced levels of lipid peroxidation, protein carbonyls, nucleic acid content, and polyamine synthesis were recorded in comparison to the control groups, which demonstrated BaP-induced lung carcinogenesis-protective effect of this compound [54]. Piperine exerts BaP-induced cytotoxicity in V-79 lung fibroblast cells, due to a decrease in GST and UDP-GT [55]. Administration of piperine reduces DNA damage and DNA-protein cross-links in the lung cancer-bearing animals. In this study, mitochondrial enzymes (isocitrate dehydrogenase (ICDH), ketoglutarate dehydrogenase (KDH), succinate dehydrogenase (SDH), malate dehydrogenase (MDH)), glutathione-metabolizing enzymes GPx, GR and glucose-6-phospho dehydrogenase(G6PDH) were significantly reduced, while NADPH-cytochrome reductase (NADPH-C reductase), cytochrome P450 (cyt-p450) and cytochrome b5(cyt-b5) showed increased levels in mice administered with piperine [56]. Also, in these animals, ATPase enzymes in erythrocyte membrane and tissues were shown to be increased, while sodium/potassium/magnesium ATPase enzyme activities decreased, showing the chemopreventive effect of piperine [57]. Lung metastasis in C57BL/6 mice 
induced by B16F-10 melanoma cells has been significantly inhibited when piperine was co-administered together with tumor induction. The results showed reduced lung collagen hydroxyproline, uronic acid, and hexosamine content, a significant decrease in tumor nodule formation and lung size and also a reduced serum sialic acid and serum r-glutamyl transpeptidase activity, pointing to very promising antimetastatic activity of piperine [58].

\subsubsection{Genital Cancers}

\section{Prostate Cancer}

When investigating the effect of piperine to voltage-gated $\mathrm{K}^{+}$channels $(\mathrm{KV})$, which play an important role in regulating cancer cell proliferation and are considered as potential targets for the treatment of cancer, it was found that it blocks voltage-gated $\mathrm{K}^{+}$current. It was effective in doses of $\mathrm{IC}_{50}=39.91 \mu \mathrm{M}$ in LNCaP and $49.45 \mu \mathrm{M}$ in PC-3 human prostate cancer cells. This recorded blockade led to $G_{0} / G_{1}$ cell cycle arrest and consequently inhibited cell proliferation and induced apoptosis [59]. In another study, on human prostate cancer DU145, PC-3 and LNCaP cells, piperine was also found to induce cell cycle arrest at $G_{0} / G_{1}$, and to cause downregulation of cyclin D1 and cyclin A, while increased levels of p21Cip1 and p27Kip1 were found upon the piperine treatment in prostate cancer cells (LNCaP and DU145). Additionally, piperine treatment resulted in promoted autophagy as evidenced by the increased level of LC3B-II and the formation of LC3B puncta [60]. In LNCaP, PC-3, and DU-145 prostate cancer cells, piperine activated caspase- 3 and cleaved PARP-1 proteins and reduced the expression of phosphorylated STAT-3 and NF-kB transcription factors [61]. A recent study determined that molecular mechanism responsible for observed repressed cell proliferation and migration (in PCa DU145 cell line) of piperine action was via affecting the expression of the Akt/mTOR/MMP-9 signaling pathway [62].

\section{Cervical and Ovarian Cancer}

Piperine and mitomycin-C (MMC) co-treatment resulted in inactivating STAT3/NF- $\mathrm{kB}$, leading to suppression of the Bcl-2 signaling pathway in human cervical cancer. Also, this compound, together with its analogs demonstrated significant potential against Hela cervix cell line [63]. A recent study showed that piperine $(8,16$, and $20 \mu \mathrm{M})$ inhibited cell viability and caused apoptosis in human ovarian A2780 cells via JNK/p38 MAPK-mediated intrinsic apoptotic pathway [64]. Further analysis on the mechanism of its action demonstrated increased levels of cyt-c from mitochondria and consequently increased caspase (caspase-3 and -9) activities and also decreased phosphorylation of JNK and p38 MAPK following piperine treatment.

\subsubsection{Cancers of the Gastrointestinal Tract}

Piperine significantly increased the levels of lipid peroxidation in 7,12-dimethyl benz [a] anthracene (DMBA)-induced hamster buccal pouch carcinogenesis. This chemopreventive efficacy of piperine was recorded by FT-IR spectroscopic technique, where decreased levels of proteins and nucleic acid content were found in comparison to untreated cancer cells [65]. In AGS human gastric cancer cells, piperine decreases Bcl-2, XIAP (anti-apoptotic), and Akt, while p53, Bax (pro-apoptotic), cleaved caspase-9, and cleaved-PARP increased [66]. Piperine inhibits IL-1 $\beta$-induced p38 MAPK and STAT3 activation and, in turn, blocks the IL-1 $\beta$-induced IL-6 expression in TMK-1 gastric cancer cells [67]. It also decreases the protein levels of Bcl-2, Mcl-1, survivin, and increases the Fas levels, resulting in inhibition of the growth of HT-29, human colon cancer cells [68]. In HT-29 colon carcinoma cells, piperine reduces the levels of cyclins (D1 and D3), cyclin-dependent kinases (CDK-4 and 6), and upregulates p21/WAF1 and p27/KIP1 expression [69]. The study of Yaffe et al. [70] found that this natural compound inhibited the growth of HRT-18 human rectal adenocarcinoma cells by causing apoptosis. The same study found that this effect has been at least partially caused by creating increased production of reactive oxygen species (ROS) in the cancer cells treated with piperine. The activation of the mechanistic target of the rapamycin complex 1 (mTORC1) was found to be associated with sustained inflammation and, 
thus, the progression of colorectal cancer. Piperine alone and in combination with curcumin plays a preventive role in the development of colorectal cancer by inhibiting TNF- $\alpha$ and mTORC1 in human intestinal epithelial cells [71].

\subsubsection{Other Cancer Types}

Piperine inhibits PKC $\alpha$ and ERK phosphorylation and reduces NF- $\mathrm{KB}$ and AP-1 activation, leading to down-regulation of MMP-9 expression in human fibrosarcoma HT-1080 cells. In B16F10 melanoma cells, piperine $(2.5,5$ and $10 \mu \mathrm{g} / \mathrm{mL})$ inhibited activation of transcription factors NF- $\mathrm{kB}$, c-Fos, cAMP response element-binding protein (CREB), activated transcription factor (ATF-2) and consequently downregulated inflammatory and growth regulatory genes IL-1 $\beta$, IL-6, TNF- $\alpha$, and granulocyte-macrophage colony-stimulating factor (GM-CSF) [72]. In ultraviolet-B-irradiated mouse melanoma cells (B16F10), piperine promotes cell death through the elevation of intracellular ROS formation, calcium homeostasis imbalance, and loss of mitochondrial membrane potential [73]. Synthetic piperine-amino acid ester conjugates exhibit cytotoxic activities against IMR-32, MCF-7, PC-3, DU-145, Colo-205, and Hep-2 cancer human cell lines [74].

\subsection{Enzyme-Related Activity}

\subsubsection{Monoamine Oxidase Activity}

Piperine exhibits antidepressant-like effects by regulating the monoaminergic system. The biochemical method of measuring the monoaminergic system is by monoamine oxidase (MAO) content, and piperine was found to inhibits this enzyme [75]. The $\mathrm{IC}_{50}$ values for MAO-A and $\mathrm{B}$ reduction by piperine were 20.9 and $7.0 \mu \mathrm{M}$, respectively [76]. Not only piperine, its related structures methylpiperate, guineensine, and piperlonguminine [77], or its derivative antiepilepsirine [78,79] exhibited a similar effect. In combination with ferulic acid, piperine exhibits a synergetic effect on MAO inhibition [80].

\subsubsection{Other Enzymes}

Piperine decreases cyt-P-450, benzphetamine N-demethylase, aminopyrine N-demethylase, and aniline hydroxylase activities [81]. Also, the basal activity of TWIK-related acid-sensitive $\mathrm{K}^{+}$channel (TASK-1, -3), and TWIK-related spinal cord $\mathrm{K}^{+}$(TRESK) channels were inhibited by piperine in a dose-dependent manner [82]. It activates transient receptor potential cation channel subfamily $\mathrm{V}$ member 1 (TRPV1) receptor, a novel anti-epileptogenic target, indicating the anti-seizure effects [83]. Chen et al. [84] recently reported the effects of piperine (5 and $10 \mathrm{mg} / \mathrm{kg}$ ) on the testis development in the pubertal rat, where piperine increased the ratio of phospho-AKT1 (pAKT1)/AKT1, phospho-AKT2 (pAKT2)/AKT2, and phospho-ERK1/2 (pERK1/2)/ERK1/2 in the testis in rats, showing a stimulating effect to the Leydig cell development.

Piperine increases GABA levels and inhibits neuronal NOS, leading to antianxiety activity in stressed mice [85]. Investigation of its effect on microsomal P450s showed diverse action, where P4501A and P4502B increased, and P4502E1 expression was suppressed in animals treated with piperine [86]. Acute acetaminophen poisoning results in increased AST and ALT levels in hepatotoxic rats. Pretreatment with piperine prevents the increased levels of these enzymes [87]. In the study which investigated the free radical scavenging properties of piperine in rat intestinal lumen model (exposed to hydrogen peroxide and cumene hydroperoxide), piperine significantly increased GSH level [88]. In MC3T3-E1 cells, piperine increases osteoblast differentiation through AMPK phosphorylation, by inhibiting of DNA binding-1, and runt-related transcription factor 2 (Runx2) [89]. Piperine inhibits phorbol 12-myristate 13-acetate (PMA) -induced NF- $\mathrm{kB}, \mathrm{C} / \mathrm{EBP}$, and c-Jun nuclear translocation, inhibits activation of the Akt and ERK, leading to inhibition of cyclooxygenase-2 expression in murine macrophages [90], and suppresses T cell activity and Th2 cytokine production in the ovalbumin-induced asthmatic mice [13]. In pilocarpine-induced epileptic rats, piperine exhibits anticonvulsant activity 
by upregulating caspase 3 and decreasing Bax/Bcl 2 [91]. Piperine lowers the serum levels of thyroxin, triiodothyronine and glucose concentrations while decreasing hepatic $5^{\prime} \mathrm{D}$ enzyme and glucose-6-phosphatase in adult male Swiss albino mice. The enzyme activities are on par with a standard antithyroid drug, propylthiouracil [92]. Piperine inhibits two carbonic anhydrases (CAs), human cytosolic isoforms hCA I and II [93]. These enzymes catalyze a physiological reaction of the conversion of $\mathrm{CO}_{2}$ to the bicarbonate ion and protons and are involved in many physiological and pathological processes including carcinogenesis. Discovery of inhibitory activity of piperine against CAs shows its potential as an anti-convulsant, analgesic, anti-tumor, and anti-obesity agent.

\subsection{Miscellaneous Activity—Kinase, Inflammation, Diabetes}

Piperine inhibits the expression of CD40 and CD86 in bone-marrow-derived dendritic cells (BMDCs), along with inhibiting TNF- $\alpha$, IL-12, but not IL-6. This eventually suppresses extracellular signal-regulated kinases and c-Jun N-terminal kinases (JNK) activation, but not p38 or NF- $\mathrm{B}$ activation [29]. Piperine activates the JNK, extracellular signal-regulated kinase and p38 MAPK pathways leading to inhibition of cisplatin-induced apoptosis in House Ear Institute-Organ of Corti I (HET-OCI) cells [94]. Piperine reverses down-regulation of adiponectin-AMP-activated protein kinase (AMPK) signaling molecules that facilitate mediating lipogenesis, fatty acid oxidation, and insulin signaling in the livers of mice. Also, it decreases the phosphorylation of insulin receptor substrate-1 (IRS-1) activity in HFD-fed mice [95]. Piperine decreases the activation of the p38-MAPK pathway, which alleviates osteoclast formation [96]. In CTLL-2T lymphocytes, piperine was found to block the IL-2-induced phosphorylation of STAT3 and STAT5 without affecting the phosphorylation of JAK 1 and JAK3, as well as to inhibit phosphorylation of extracellular signal-regulated kinase $1 / 2$ and Akt. The same study showed that piperine also suppresses the expression of cyclin-dependent kinase (Cdk)1, Cdk4, Cdk6, cyclin B, and cyclin D2 [97]. The results of the study of Doucette et al. [98] showed that piperine inhibits the phosphoinositide-3 kinase/Akt signaling pathway, HUVEC proliferation and collagen-induced angiogenesis, which plays a vital role in tumor progression. In T-lymphocytes, piperine decreases the expression of cyclin D3, CDK4, and CDK6, inhibits CD25 expression, IL-2, IL-4, and IL-17A and this effect was associated with inhibition of Akt hypophosphorylation [99]. The study on piperine effect to LPS-stimulated human epithelial-like SW480, and HT-29 cells showed that it downregulates the MAPK pathways [100]. Piperine stimulates the p38 MAPK and induces the phosphorylation of AMP-activated protein kinase [101]. The study of Kumar et al. [102] found that piperine inhibits TNF- $\alpha$, intercellular adhesion molecule- 1 , vascular cell adhesion molecule- 1 and E-selectin. Also, by attenuating TNF- $\alpha$, piperine prevents the phosphorylation and degradation of $I \kappa B \alpha$ [102]. Piperine decreases the vascular smooth muscle cells by increasing the expression of p27kip1, decreasing cell cycle enzymes (cyclin D, cyclin E, and proliferating cell nuclear antigen), phosphorylation of extracellular signal-regulated kinase (ERK)1/2, and phosphorylation of the p38 MAPK [103]. Also, by down-regulating miR-127, MyD88 expression, NF-kB, and p38 MAPK signaling pathways activation, piperine may act as osteoarthritis therapeutic agent in murine chondrogenic ATDC 5 cells [104]. Piperine activates PPAR $\gamma$, leading to inhibition of AKT/GSK3 $\beta$ and reduction of cardiac fibrosis [105]. As piperine phosphorylates AMP-activated protein kinase, facilitates glucose transporter 4 to enter the plasma membrane, increase the intracellular $\mathrm{Ca} 2+$ level and activation of $\mathrm{Ca} 2+/$ calmodulin-dependent protein kinase kinase-beta, it also possesses hyperglycemia-preventing effect [106]. Piperine may act as a novel therapeutic agent for melanoma, as it increases the ratio of Bax and Bcl-2, upregulates the expression of apoptosis-inducing factor, and reduces UVB-induced p-glycoprotein activity in B16F10 mouse melanoma cells [73]. Zhang et al. [107] found that in HOS and U2OS osteosarcoma cells, administration of piperine decreases cyclin B1 and increases phosphorylation of cyclin-dependent kinase-1 and checkpoint kinase 2. Also, inhibited phosphorylation of Akt and activated phosphorylation of c-Jun N-terminal kinase (c-JNK) and p38 MAPK were recorded, pointing to suppression of the metastasis by this natural compound [107]. Piperine was found to be beneficial for 
tendinopathy, since it inhibits MMP-2, MMP-9, ERK and p38 signaling pathways in collagenase-induced Achilles tendon injury in the rat [108].

\subsection{Neuroprotective and Other Neurological Effects of Piperine}

Piperine increases the cell viability and restored mitochondrial functioning and primary neurons in rotenone-induced neurotoxicity in SK-N-SH cells. It also inhibits mTORC1 and activates protein phosphatase 2A, leading to neuroprotective effects in Parkinson's disease model [109]. This compound exerts protective effects against neurotoxicity induced by corticosterone (PC12 Cells) [110] and 1-methyl-4-phenyl-1,2,3,6-tetrahydropyridine [111]. Also, piperine exhibits the neuroprotective effect on primarily cultured hippocampal neurons [112] and suppresses the neurite extension in developing neurons [113].

In rats with streptozotocin (STZ)-induced experimental dementia of the Alzheimer's type, intraperitoneal administration of piperine $(2.5,5$, and $10 \mathrm{mg} / \mathrm{kg})$, vehicle, and memantine $(10 \mathrm{mg} / \mathrm{kg})$ for two weeks after the first STZ administration resulted with cognitive-enhancing effect. The results of cognitive function were consistent with a reduced level of malondialdehyde in cerebrospinal fluid (CSF) and hippocampus (HC) of the treated rats. Based on the described results, the cognitive-enhancing effect of piperine was attributed to its positive effects on the redox balance of CSF and HC neurons [114]. In a pilocarpine-induced rat model of epilepsy, administration of piperine reduced oxidative stress and inflammation and ameliorated memory impairment [91]. Piperine alone was found to produce a weak antidepressant-like effect in the tail suspension and forced swimming tests, while in combination with trans-resveratrol $(\mathrm{tR})$ it enhanced its antidepressive action.

Further testing indicated that the effect of $\mathrm{tR}$ and piperine on depressive-like behaviors might be partly due to the potentiated activation of monoaminergic system in the brain [75]. Similar results were found in several other studies on piperine alone [76], in combination with ferulic acid [80], and its various derivatives [77-79]. Piperine relieves the depression in chronic unpredictable mild stress rats by modulating the function of the hypothalamic-pituitary-adrenal axis [115].

Piperine was found to possess analgesic and anticonvulsant effects, where intraperitoneal (i.p.) administration of piperine $(30,50$ and $70 \mathrm{mg} / \mathrm{kg}$ ) significantly inhibited the acetic acid-induced writhing in mice, while tail-flick assay resulted in prolonged reaction time of mice at doses of 30 and $50 \mathrm{mg} / \mathrm{kg}$. The anticonvulsant effect of piperine has been demonstrated through delayed onset of pentylenetetrazole- and picrotoxin-induced seizures in mice [116]. These anti-seizure effects of piperine were found to be related to transient receptor potential cation channel subfamily $\mathrm{V}$ member 1 (TRPV1) receptors [83]. Another study reported analgesic activity of piperine, where hot plate reaction test and acetic acid test were used and confirmed analgesic efficacy of intraperitoneally administered piperine [39].

\subsection{Negative Aspects of Piperine}

At high doses, piperine is acutely toxic to mice, rats, and hamsters. The $\mathrm{LD}_{50}$ values for a single i.v., i.p., s.c., i.g. and i.m. administration of piperine to adult male mice were 15.1, 43, 200, 330, and $400 \mathrm{mg} / \mathrm{kg}$ body wt, respectively [117]. Considering oral application, $\mathrm{LD}_{50}$ values were shown to be $330 \mathrm{mg} / \mathrm{kg}$ in mice and $514 \mathrm{mg} / \mathrm{kg}$ in rats [117]. Piperine increases serum aspartate aminotransferase and ALP, while total serum protein decreased, which results in considerable damage to the liver in CF-1 albino mice [118]. Administration of piperine enhances the aflatoxin B1 binding to calf thymus DNA in vivo in rat tissues [119]. In the study of D'cruz and Mathur [37], which studied the effect of piperine on the epididymal antioxidant system of adult male rats, a negative effect was recorded throuh reduced weights of the caput, corpus and cauda regions of the epididymis. Also, the results pointed to decreased sperm count, motility and viability, decreased levels of sialic acid and also a decrease in the activity of antioxidant enzymes at a dose of $100 \mathrm{mg} / \mathrm{kg}$. Therefore, due to increased ROS levels in the epididymis, sperm function can be damaged by intake of piperine. Similar effects of piperine were recently reported for pubertal rats administered with piperine ( 5 and $10 \mathrm{mg} / \mathrm{kg}$ ) for 30 days. In the 
mentioned study, piperine increased testosterone (T) and follicle-stimulating hormone (FSH) levels, number and size of Leydig cells, but negatively affected spermatogenesis [84]. This was partially opposite to the results of the earlier study, which reported only negative effects of piperine to testes, and performed the same treatment of mature male albino rats (administered for 30 days at the same doses of 5 and $10 \mathrm{mg} / \mathrm{kg}$ ). The results of this study showed that lower dose caused partial degeneration of germ cell types, while a higher dose, on the other hand, caused severe damage to the seminiferous tubule, a fall in caput and cauda epididymal sperm concentrations, decrease in seminiferous tubular and Leydig cell nuclear diameter and desquamation of spermatocytes and spermatids. In these, piperine treated rats, an increase in serum gonadotropins, and a decrease of intratesticular $\mathrm{T}$ concentration were reported as well [120].

\subsection{Antimicrobial Activity of Piperine}

Piperine has not been extensively studied with respect to its antimicrobial potential, but several performed antimicrobial assays have demonstrated the wide range, but moderate inhibitory action, of this compound. In the study of Aldaly [121], piperine was inhibitory against a spectrum of test microorganisms in the range $3.12-100 \mathrm{mg} / \mathrm{mL}$ and exhibited the highest activity against a fungal strain Candida albicans. In the study of Umadevi et al. [52], it was found that its activity ranged from $100-600 \mu \mathrm{g} / \mathrm{mL}$ and that it exhibited the best inhibitory potential against Pseudomonas aeruginosa. Recently, this effect was confirmed for four tested bacterial strains [122]. It has been reported that piperine enhances the antimicrobial action of ciprofloxacin against Escherichia coli and Bacillus subtilis [123]. Piperine decreases the efflux of ethidium bromide, thereby inhibiting mycobacterial efflux pump in Mycobacterium smegmatis [124]. Piperine derivatives having pyridine scaffold were synthesized by Amperayani et al. [125] and observed that they exhibit antimicrobial activity when tested against B. subtilis, Streptobacillus sp., Staphylococcus aureus, E. coli, Salmonella typhi, Aspergillus niger, A. flavus, and A. fumigatus.

To the best of our knowledge, scientific research on piperine in food models have not been reported yet, but studies have confirmed the efficacy of black pepper in microbiological preservation against Listeria monocytogenes in fermented sausages [126] and S. aureus in cheese [127], as well as against general microbial load [128-130]. The efficacy of black and white pepper in food preservation was also reported in the sense of lowering lipid oxidation $[128,131]$ and increasing the sensory quality and shelf life of the treated food samples $[129,132,133]$. Since piperine represents a major constituent of the pepper, it contributes at least partially to these activities. Therefore, future studies should focus on investigations of the pure piperine in this sense.

Piperine derivatives with electronegative atoms, large volumes, an ester group, the absence of unsaturation on a side chain, carboxyl group possess anti-leishmanial activity against promastigote forms [134]. Piperine inhibits promastigotes of Leishmania donovani [135], while some of the piperine derivatives and analogs are anti-leishmanial towards L. amazonensis [136]. Piperine and its derivatives exert a toxic effect on epimastigotes and amastigotes of Trypanosoma cruzi [137].

\subsection{Bioavailability-Enhancing Effect of Piperine}

Piperine increases the bioavailability of the coenzyme Q10 in plasma in a nonspecific fashion when orally administered [138]. The pharmacokinetics of ciprofloxacin changed when piperine was co-administered, emphasizing the fact that it acts as bioenhancer [139]. Similar results were reported for amoxicillin [140], rosuvastatin [141], omeprazole [142], magnolol [143], ampicillin and norfloxacin [144]. Piperine, as a bio enhancer, improves the systemic availability of oral propranolol and theophylline in healthy volunteers [145]. Similar results were obtained with carbamazepine, chlorzoxazone, fexofenadine, diclofenac, dexibuprofen [146], midazolam [147], resveratrol and nevirapine [148], vasicine and sparteine [149], as well as tamoxifen and endoxifen [150]. When piperine was combined with phenytoin, it increased its absorption, decreased the absorption half-life, and prolonged the elimination half-life $\left(\mathrm{T}_{1 / 2}\right)$, and produced a higher area under the drug concentration curve (AUC) in 
comparison to phenytoin alone [151-153]. The new pharmacological preparation Risorine, composed of rifampicin, piperine and isoniazid, provides better results considering the cure rate [154] and more rifampicin in blood along with higher safety in comparison to standard antituberculosis therapy [155]. When orally administered with curcumin, it was found that piperine enhances its oral bioavailability in humans $[156,157]$, while when taken together with $\beta$-carotene, significantly greater increases in serum $\beta$-carotene occurred, pointing to the absorption-enhancing effect of piperine [158]. Also, piperine in the form of pro-nanolipospheres was found to be efficient in overcoming the limitations of variable and low oral bioavailability of cannabinoids tetrahydrocannabinol and cannabidiol [159]. Piperine increases the bioavailability of emodin in rats [160], linarin [161], $\beta$-lactam antibiotics [162], fexofenadine [163], ginsenoside Rh2 [164], (-)-epigallocatechin-3-gallate [165], puerarin [166], oxyphenylbutazone [167] and diltiazem [168]. In a study on human cancer cell line (monolayers of Caco-2 cells), Bhardwaj et al. [169] found piperine to be an inhibitor of both human P-glycoprotein and CYP3A4, and that it also inhibited transport of the P-glycoprotein substrates digoxin and cyclosporine. Another study, performed on intestinal epithelial cells derived from a human ileocecal adenocarcinoma (HCT-8; ATCC No. CCL-244), found that piperine significantly increased the transepithelial electrical resistance of the cell monolayer [170]. At concentrations ranging from 50 and $100 \mu \mathrm{M}$, prolonged co-incubation of Caco-2 cell monolayers with piperine increased P-gp activity through an up-regulation of cellular P-gp protein and MDR1 mRNA levels [171]. Co-administration of [172] increased docetaxel's pharmacokinetic activity on castration-resistant prostate cancer cells via inhibition of hepatic CYP3A4 activity, which resulted in an increased AUC, $T_{1 / 2}$ and maximum plasma concentration $\left(\mathrm{C}_{\max }\right)$ of docetaxel [172]. Piperine increases the $C_{\max }$ and the elimination $T_{1 / 2}$ of domperidone in rats [173].

\section{Piperine: Human Clinical Trials}

\subsection{Effect of Piperine on Oral Bioavailability of Drugs and Natural Therapeutic Compounds}

Most human clinical studies have been focused on bioavailability enhancement by co-administration of piperine with various drugs (Table 1). In these trials, various groups of drugs were found to be more effective and stayed longer in plasma when administered with piperine. One of the earliest studies was that of Atal et al. [149], which used $\left[{ }^{3} \mathrm{H}\right]$ vasicine and $\left[{ }^{3} \mathrm{H}\right]$ sparteine as test drugs, together with piperine, and found that sparteine blood levels increased more than $100 \%$, while vasicine levels increased by nearly $233 \%$ when applied together with piperine. Based on this early study, another set of studies on humans investigated the effect of piperine co-administration with phenytoin and found that a single daily dose of piperine decreased the absorption $T_{1 / 2}$, prolonged the elimination $\mathrm{T}_{1 / 2}$, and produced a higher AUC in comparison to phenytoin alone [151]; as well as increasing the absorption rate constant $(\mathrm{K}(\mathrm{a})), \mathrm{AUC}(0-48 \mathrm{~h})^{\prime}, \mathrm{AUC}(\mathrm{o}-\infty)^{\prime}$, delaying elimination of phenytoin [152], and increasing AUC (0-12 h), $C_{\max }$ and $\mathrm{K}(\mathrm{a})$ [153]. These results demonstrated the alteration of the pharmacokinetic parameters of this antiepileptic drug, as well as the enhanced bioavailability of phenytoin when applied with piperine. Another study on the effect of piperine on the bioavailability and pharmacokinetics of the drugs propranolol and theophylline demonstrated an earlier $\mathrm{T}_{\max }$, and a higher $C_{\max }$ and AUC in the subjects who received piperine together with propranolol. Considering co-administration of piperine and theophylline, a higher $C_{\max }$, longer elimination half-life, and a higher AUC were observed [145]. Shoba et al. [156] reported that concomitant administration of piperine with curcumin produced much higher concentrations of this bioactive compound $(0.25$ to $1 \mathrm{~h}$ post-drug), as well as the increase in its bioavailability of $2000 \%$. Combination of dexibuprofen with the multi-ingredient formula (Lipicur composed of lipoic acid, curcumin, and piperine) reduced neuropathic pain by more than $66 \%$ in subjects with lumbar sciatica and carpal tunnel syndrome, as well as by about $40 \%$ with dexibuprofen use [146]. 
Table 1. Clinical trials on the effect of piperine on the bioavailability of drugs and natural therapeutic compounds.

\begin{tabular}{|c|c|c|c|c|}
\hline Effect of Piperine & No of Patients/Study Design & Trial Length & Treatment, Dose and Formulation of Piperine & Ref. \\
\hline $\begin{array}{l}\stackrel{\text { Phenytoin }}{\downarrow \text { absorption } \mathrm{T}_{1 / 2}} \\
\uparrow \mathrm{T}_{1 / 2 \mathrm{el}} \\
\uparrow \mathrm{AUC} \\
\uparrow \mathrm{Cmax}\end{array}$ & $\begin{array}{l}5 \text { healthy volunteers a crossover } \\
\text { study }\end{array}$ & 7 days & $\begin{array}{l}\text { single oral dose ( } 300 \mathrm{mg}) \text { of phenytoin alone or multiple doses of } \\
\text { piperine ( } 20 \mathrm{mg} \text { daily for } 7 \text { days), followed by an oral dose of } \\
\text { phenytoin. }\end{array}$ & [151] \\
\hline $\begin{array}{l}\frac{\text { Phenytoin }}{\uparrow K a} \\
\uparrow \mathrm{AUC}_{0-48} \\
\uparrow \mathrm{AUCo- \infty} \\
\uparrow \mathrm{T}_{1 / 2} \mathrm{el} \\
\end{array}$ & $\begin{array}{l}6 \text { healthy volunteers a crossover } \\
\text { study }\end{array}$ & A single dose & $\begin{array}{c}\text { Phenytoin single oral dose }(300 \mathrm{mg}) \text { was given to participants } 30 \mathrm{~min} \\
\text { following ingestion of a soup with/without black pepper }(1 \mathrm{~g} / 200 \mathrm{~mL}) \\
2 \text { weeks washout period } \\
\text { Interchanging of the groups }\end{array}$ & [152] \\
\hline $\begin{array}{c}\text { Phenytoin } \\
\uparrow \mathrm{AUC}_{0-12 \mathrm{~h}} \\
\uparrow \mathrm{Cmax} \\
\uparrow \mathrm{Ka} \\
\text { Kel and Tmax unchanged }\end{array}$ & 2 groups of 10 patients & A single dose & $\begin{array}{l}\text { Phase I: } \\
\text { Group } 1 \text { received } 150 \mathrm{mg} \text { of phenytoin twice daily. } \\
\text { Group } 2 \text { received } 200 \mathrm{mg} \text { dose of phenytoin twice daily. } \\
\text { Phase II: } 20 \mathrm{mg} \text { of piperine was administered along with phenytoin } \\
\text { (150 or } 200 \mathrm{mg}) \text {. }\end{array}$ & [153] \\
\hline $\begin{array}{c}\text { Propranolol and theophylline } \\
\text { Piperine with propranolol: } \\
\uparrow \text { Cmax } \\
\uparrow \mathrm{AUC} \\
\text { Piperine with theophylline: } \\
\uparrow \mathrm{Cmax}, \\
\uparrow \mathrm{T}_{1 / 2} \mathrm{el} \\
\uparrow \mathrm{AUC} \\
\text { A }\end{array}$ & $\begin{array}{l}6 \text { healthy male volunteers } \\
\text { a randomized crossover study }\end{array}$ & 7 days & $\begin{array}{l}\text { Phase I: } \\
\text { Group } 1 \text { received a single oral dose of propranolol }(40 \mathrm{mg}) \\
\text { Group } 2 \text { received a single oral dose of theophylline }(150 \mathrm{mg}) \\
\text { Phase II: piperine } 20 \mathrm{mg} \text { daily for } 7 \text { days following administration of } \\
\text { drugs. } \\
\text { One week was permitted as a washout period between the two } \\
\text { treatments. }\end{array}$ & [145] \\
\hline $\begin{array}{l}\text { Curcumine } \\
\text { Concomitant administration of piperine }(20 \mathrm{mg}) \text { produced much } \\
\text { higher concentrations from } 0.25 \text { to } 1 \mathrm{~h} \text { post drug and the increase in } \\
\text { bioavailability of } 2000 \% \text {. }\end{array}$ & $\begin{array}{l}10 \text { healthy male volunteers a } \\
\text { randomized crossover study }\end{array}$ & Four weeks & $\begin{array}{l}\text { Phase I: } 2 \mathrm{~g} \text { of pure curcumin powder }(4 \times 500 \mathrm{mg}) \text { was given with } \\
\qquad 150 \mathrm{~mL} \text { of water. } \\
\text { Phase II: } 2 \mathrm{~g} \text { of pure curcumin powder combined with } 20 \mathrm{mg} \text { of pure } \\
\text { piperine powder }(4 \times 500 \mathrm{mg} \text { curcumin }+5 \mathrm{mg} \text { piperine each) was } \\
\text { given with } 150 \mathrm{~mL} \text { of water. }\end{array}$ & [156] \\
\hline $\begin{array}{c}\text { Curcuminoids } \\
\downarrow \text { absorption } \mathrm{T}_{1 / 2} \\
\uparrow \mathrm{Cmax} \\
\uparrow \mathrm{Tmax} \\
\uparrow \mathrm{Ke} \\
\uparrow \mathrm{AUCo- \infty} \\
\uparrow \mathrm{Cl} / \mathrm{F} \\
\uparrow \mathrm{Vz} / \mathrm{F} \\
\text { Piperine with lecitine formula increases curcumin bioavailibility } \\
\text { when compared with control curcumin }\end{array}$ & $\begin{array}{l}11 \text { healthy participants a pilot, } \\
\text { crossover study }\end{array}$ & Six weeks & $\begin{array}{c}\begin{array}{r}\text { Group } 1 \text { consumed } 4 \times 500 \mathrm{mg} \text { capsules of } \mathrm{BCM}-95^{\circledR} \mathrm{C} \\
\text { (Biocurcumax }\end{array} \\
\text { Group } 2 \text { consumed control curcumin } \\
\text { Group } 3 \text { consumed equivalent doses of curcumin-lecithin-piperine } \\
\text { formula. }\end{array}$ & [157] \\
\hline
\end{tabular}


Table 1. Cont.

\begin{tabular}{|c|c|c|c|c|}
\hline Effect of Piperine & No of Patients/Study Design & Trial Length & Treatment, Dose and Formulation of Piperine & Ref. \\
\hline $\begin{array}{l}\text { Dexibuprofen } \\
\text { multi-ingredient formula Lipicur containing piperine reduced } \\
\text { neuropathic pain by more than } 66 \% \text { in both conditions } \\
\text { The treatment reduced dexibuprofen use by about } 40 \% \text {. }\end{array}$ & $\begin{array}{l}141 \text { subjects affected by } \\
\text { neuropathic pain open } \\
\text { randomized control clinical } \\
\text { study }\end{array}$ & Eight weeks & $\begin{array}{l}\text { Group } 1 \text { received two tablets/day of Seractil containing dexibuprofen } \\
\text { (400 mg/tablet) } \\
\text { Group } 2 \text { received two tablets/ day of Seractil plus two tablets/day of } \\
\text { Tiobec } 400 \text { containing lipoic acid, } 400 \mathrm{mg} / \text { tablet } \\
\text { Group } 3 \text { received two tablets/day of Seractil plus two tablets/day of } \\
\text { Lipicur containing } 400 \mathrm{mg} \text { lipoic acid, } 400 \mathrm{mg} \text { curcumin phytosome } \\
\text { and } 4 \mathrm{mg} \text { piperine. }\end{array}$ & [146] \\
\hline $\begin{array}{c}\text { Piperine amoxifen and endoxifen } \\
\text { and curcumine adjunctive therapy: } \\
\text { Tamoxifen } \\
\downarrow \mathrm{AUC}_{0-24 \mathrm{~h}}(13 \%) \\
\text { Endoxifen } \\
\downarrow \mathrm{AUC}_{0-24 \mathrm{~h}}(13.5 \%)\end{array}$ & $\begin{array}{c}15 \text { patients } \\
\text { two-arm, three-period, } \\
\text { randomized, cross-over study }\end{array}$ & $\begin{array}{l}\text { January } \\
\text { 2017-May } \\
2018\end{array}$ & $\begin{array}{l}\text { Cycle 1: patients received tamoxifen monotherapy } \\
\text { Cycle 2: patients received tamoxifen + curcumin (three times daily } \\
1.200 \mathrm{mg} \text { ) } \\
\text { Cycle 3: patients received tamoxifen concomitantly with curcumin } \\
\text { and piperine (three times daily } 1.200 \mathrm{mg} \text { and three times daily } 10 \mathrm{mg} \text {, } \\
\text { respectively) }\end{array}$ & [150] \\
\hline$\frac{\text { Beta-carotene }}{\uparrow \mathrm{AUC}(60 \%)}$ & $\begin{array}{l}\text { a double-blind, placebo } \\
\text { controlled, crossover study }\end{array}$ & 14 days & $\begin{array}{l}\text { a daily beta-carotene dose }(15 \mathrm{mg}) \text { either with } 5 \mathrm{mg} \text { of piperine or } \\
\text { placebo }\end{array}$ & [158] \\
\hline$\frac{\text { Coenzyme Q10 }}{\uparrow \mathrm{AUC}(30 \%)}$ & 12 healthy adult male subjects & 21 days & $\begin{array}{c}\text { Control group: } \\
\text { coenzyme Q10 (30 mg/capsule) + placebo, administered together in a } \\
\text { single dose ( } 90 \mathrm{mg} / \text { day), } 14 \text { day }(90 \mathrm{mg} / \text { day) and } 21 \text {-day } \\
\text { supplementation (120 mg of Q10/day). } \\
\text { Treatment group: coenzyme Q10 + } 5 \text { mg piperine. }\end{array}$ & [138] \\
\hline $\begin{array}{c}\text { Carbamazepine } \\
\text { Both dose groups }(300 \text { and } 500 \mathrm{mg}): \\
\uparrow A \mathrm{AU}_{0-12} \\
\uparrow \text { average Css } \\
\uparrow \mathrm{T}_{1 / 2} \mathrm{el} \\
\downarrow \text { Kel } \\
\text { In } 500 \mathrm{mg} \text { dose group: } \\
\uparrow \mathrm{Cmax} \\
\uparrow \mathrm{T}(\max )\end{array}$ & 10 patients & A single dose & $\begin{array}{c}\text { Piperine (20 mg p.o.) }+300 \mathrm{mg} \text { or } 500 \mathrm{mg} \text { dose of carbamazepine } \\
\text { twice daily }\end{array}$ & [174] \\
\hline $\begin{array}{l}\text { Carbamazepine } \\
\uparrow \operatorname{AUC}(47.9 \%) \\
\uparrow \operatorname{Cmax}(68.7 \%) \\
\uparrow \mathrm{T}_{1 / 2}(43.2 \%)\end{array}$ & $\begin{array}{l}12 \text { healthy volunteers } \\
\text { an open-label, } 2 \text { period, } \\
\text { sequential study }\end{array}$ & 10 days & $\begin{array}{l}\text { Piperine (20 mg p.o.) was administered once daily for } 10 \text { days during } \\
\text { treatment phase. A single dose of carbamazepine } 200 \mathrm{mg} \text { was } \\
\text { administered during control and after treatment phases under fasting } \\
\text { conditions. }\end{array}$ & [175] \\
\hline
\end{tabular}


Table 1. Cont

\begin{tabular}{|c|c|c|c|c|}
\hline Effect of Piperine & No of Patients/Study Design & Trial Length & Treatment, Dose and Formulation of Piperine & Ref. \\
\hline 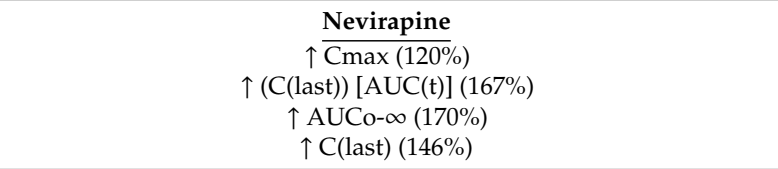 & $\begin{array}{l}12 \text { healthy adult males } \\
\text { a randomised, crossover, } \\
\text { placebo-controlled pilot study }\end{array}$ & 7 days & $\begin{array}{c}\text { Piperine }(20 \mathrm{mg}) \text { or placebo each morning for } 6 \text { days } \\
\text { Day } 7 \text { : } \\
\text { nevirapine } 200 \mathrm{mg}+\text { piperine } 20 \mathrm{mg} \text { or nevirapine + placebo in a } \\
\text { crossover fashion }\end{array}$ & [148] \\
\hline 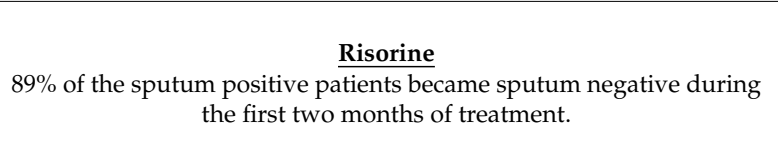 & $\begin{array}{l}33 \text { patients with pulmonary } \\
\text { tuberculosis } \\
\text { A pilot study }\end{array}$ & 6 months & $\begin{array}{c}\text { Months } 1 \text { and 2: } \\
\text { Daily oral therapy consisting of one capsule of Risorine, one tablet of } \\
\text { ethambutol }(800 \mathrm{mg}) \text { and two tablets of Pyrazinamide (750 mg each) } \\
\text { Months 3-6: } \\
\text { Daily oral therapy consisting of one capsule of Risorine }\end{array}$ & [154] \\
\hline $\begin{array}{l}\text { Risorine } \\
\text { treatment resulted with: } \\
\text { Higher sputum conversion rate }(93 \%) \text { vs. control group (84\%) at } 4 \\
\text { weeks } \\
\text { Higher cure rate at the end of } 24 \text { weeks }(92 \%) \text { vs. control group ( } 82 \%) \\
\text { Decreased side effects (3 patients vs. } 9 \text { patients in control group). }\end{array}$ & $\begin{array}{l}216 \text { patients with tuberculosis } \\
\text { randomized, triple-blind, } \\
\text { parallel-group, multi-center, } \\
\text { comparative clinical phase III } \\
\text { study }\end{array}$ & 6 months & $\begin{array}{l}\text { patients were randomized into: } \\
\text { Control group, receiving a conventional anti-TB therapy }(n=117) \text { or } \\
\text { Treatment group, receiving a similar regimen + Risorine }(n=99) \text {. }\end{array}$ & [155] \\
\hline $\begin{array}{c}\text { Midazolam } \\
\text { Higher duration of sedation } \\
\uparrow \mathrm{T}_{1 / 2} \\
\uparrow \mathrm{Cl} / \mathrm{F}\end{array}$ & $\begin{array}{l}20 \text { healthy volunteers } \\
\text { A randomized, cross-over } \\
\text { controlled study }\end{array}$ & 4 days & $\begin{array}{l}\text { volunteers received oral dose of piperine }(15 \mathrm{mg}) \text { or placebo for three } \\
\text { days as pretreatment and midazolam }(10 \mathrm{mg}) \text { on fourth day of study } \\
\text { One month of clearance }\end{array}$ & [147] \\
\hline $\begin{array}{c}\frac{\text { Resveratrol }}{\text { Increased CBF }} \\
\text { Cognitive function, mood and blood pressure were not changed. }\end{array}$ & $\begin{array}{l}23 \text { adults } \\
\text { a randomised, double-blind, } \\
\text { placebo-controlled trial }\end{array}$ & $\begin{array}{l}\text { Three single } \\
\text { doses }\end{array}$ & $\begin{array}{l}\text { the participants received three single-dose treatments comprised of } \\
\text { two capsules, containing either an inert placebo, } 250 \mathrm{mg} \text { of } \\
\text { trans-resveratrol or } 250 \mathrm{mg} \text { of trans-resveratrol }+20 \mathrm{mg} \text { of piperine. }\end{array}$ & [176] \\
\hline $\begin{array}{c}\frac{\text { Chlorzoxazone }}{\uparrow \text { Cmax (157\%) }} \\
\uparrow \mathrm{AUC}(170 \%) \\
\uparrow \mathrm{T}_{1 / 2}(144 \%) \\
\downarrow \text { Kel (by 39\%) } \\
\downarrow \mathrm{Cl} / \mathrm{F}(\text { by } 81 \%) \\
\text { 6-hydrochlorzoxazone } \\
\downarrow \text { Cmax (by } 46 \%) \\
\downarrow \mathrm{AUC} \text { (by 38\%) } \\
\left.\downarrow \mathrm{T}_{1 / 2} \text { (by } 51 \%\right) \\
\uparrow \mathrm{Kel}(134 \%) \\
\downarrow \text { metabolite to parent (6-OHCHZ/CHZ) ratios of Cmax, AUC, } \mathrm{T} 1 / 2 \\
\uparrow \text { Kel ratio of 6-OHCHZ/CHZ }\end{array}$ & $\begin{array}{l}12 \text { healthy volunteers } \\
\text { an open-label, two period, } \\
\text { sequential study }\end{array}$ & 10 days & $\begin{array}{l}\text { A single dose of piperine }(20 \mathrm{mg}) \text { was administered daily for } 10 \text { days } \\
\text { during treatment phase. A single dose of chlorzoxazone } \\
250 \mathrm{mg} \text { was administered during control and after treatment phases } \\
\text { under fasting conditions. }\end{array}$ & [177] \\
\hline
\end{tabular}

$\uparrow$ Kel ratio of 6-OHCHZ/CHZ 
Table 1. Cont

\begin{tabular}{|c|c|c|c|c|}
\hline Effect of Piperine & No of Patients/Study Design & Trial Length & Treatment, Dose and Formulation of Piperine & Ref. \\
\hline $\begin{array}{c}\text { Diclofenac } \\
\uparrow \text { Cmax }(164 \%) \\
\uparrow \mathrm{AUC}(166 \%) \\
\uparrow \mathrm{T}_{1 / 2}(134 \%) \\
\downarrow \mathrm{Kel}(\text { by } 51 \%) \\
\downarrow \mathrm{Cl} / \mathrm{F}(\text { by } 67 \%)\end{array}$ & $\begin{array}{l}12 \text { healthy volunteers } \\
\text { the open-label, two period, } \\
\text { sequential study }\end{array}$ & A single dose & $\begin{array}{l}\text { A single dose of piperine } 20 \mathrm{mg} \text { was administered daily for } 10 \text { days } \\
\text { during treatment phase. A single dose of Diclofenac sodium } 100 \mathrm{mg} \\
\text { was administered during control and after treatment phases under } \\
\text { fasting conditions. }\end{array}$ & [178] \\
\hline $\begin{array}{l}\text { Fexofenadine } \\
\uparrow \text { Cmax }(188 \%) \\
\uparrow \operatorname{AUC}(168 \%) \\
\downarrow \mathrm{Cl} / \mathrm{F}(\text { by } 71 \%)\end{array}$ & $\begin{array}{l}12 \text { healthy male volunteers } \\
\text { an open-label, two-period, } \\
\text { sequential study }\end{array}$ & A single dose & $\begin{array}{l}\text { A single dose of piperine }(20 \mathrm{mg}) \text { was administered daily for } 10 \text { days } \\
\text { during treatment phase. A single dose of FEX ( } 120 \mathrm{mg}) \text { was } \\
\text { administered during control and after treatment phases under fasting } \\
\text { conditions. }\end{array}$ & [179] \\
\hline $\begin{array}{l}\text { Cannabinoids } \\
\text { Effect to THC: } \\
\text { 3-fold increase in Cmax } \\
\text { 1.5-fold increase in AUC } \\
\text { Effect to CBD: } \\
\text { 4-fold increase in Cmax } \\
\text { 2.2-fold increase in AUC }\end{array}$ & $\begin{array}{l}9 \text { healthy volunteers } \\
\text { a two-way crossover, single } \\
\text { administration }\end{array}$ & A single dose & $\begin{array}{l}\text { Each subject received a THC-CBD }(10.8 \mathrm{mg}, 10 \mathrm{mg} \text { respectively }) \\
\text { piperine }(20 \mathrm{mg}) \text {-PNL filled capsule and an equivalent dose of the } \\
\text { oromucosal spray Sativex }{ }^{\circledR} \text { with a washout period in between } \\
\text { treatments }\end{array}$ & [159] \\
\hline
\end{tabular}

$\mathrm{Kel}$-elimination rate constant; $\mathrm{T}_{1 / 2}$ - half-life; $\mathrm{T}_{1 / 2} \mathrm{el}$ - elimination half-life; THC—-tetrahydrocannabinol. 
Also, it was found that when piperine was combined with $\beta$-carotene, a significantly greater increase ( $60 \%$ greater AUC) in serum $\beta$-carotene occurred during oral supplementation with these two compounds [158]. The same authors [138] found that piperine supplementation may result in improved absorption of coenzyme Q10, but also demonstrated that this effect has dose and time dependency. Another natural compound, phytoalexin resveratrol, has been reported to be more bioavailable when co-supplemented with piperine. When administered together, a significant augmentation of cerebral blood flow during task performance was found in comparison with placebo and resveratrol alone, but without affecting cognitive function, mood or blood pressure [176]. Co-administration of diclofenac together with piperine resulted in enhanced $C_{\max }, A U C, T_{1 / 2}$ and significantly decreased elimination rate constant $\left(\mathrm{K}_{\mathrm{el}}\right)$ and apparent oral clearance $(\mathrm{CL} / \mathrm{F})$ of the investigated drug in comparison to the control phase [178]. The antiepileptic drug carbamazepine was studied when administered alone or with piperine in poorly controlled epilepsy patients, and it was found that piperine significantly increased $\mathrm{AUC}_{0-12}$, average $\mathrm{C}_{\mathrm{ss}}$, elimination $\mathrm{T}_{1 / 2}$ and decreased $\mathrm{K}_{\mathrm{el}}$ [174]. In healthy subjects, piperine treatment significantly enhanced $C_{\max }, A U C$, and $T_{1 / 2}$ of carbamazepine by $68.7,47.9$ and $43.2 \%$, while $\mathrm{K}_{\mathrm{el}}$ and CL/F decreased when compared to the control without piperine [175]. Another anticonvulsant drug, midazolam, when taken by healthy subjects in combination with piperine, had increased $\mathrm{T}_{1 / 2}$ and decreased clearance when compared to placebo [147]. When piperine was co-administered with nevirapine, a potent non-nucleoside inhibitor of HIV-1 reverse transcriptase, $\mathrm{C}_{\max }$, AUC-time curve from $0 \mathrm{~h}$ to the last measurable concentration $\left(\mathrm{C}_{\text {last }}\right)$ [AUC( $\left.\mathrm{t}\right)$ ], AUC extrapolated to infinity $\left(A U C_{\text {infinity }}\right)$ and $C_{\text {last }}$ values of nevirapine increased by approximately $120 \%, 167 \%, 170 \%$, and $146 \%$, respectively [148]. Piperine was found to be highly effective in improving the results of tuberculosis treatment with Risorine (capsules composed of Rifampicin 200 mg + Isoniazid 300 mg + Piperine $10 \mathrm{mg}$ ) given along with ethambutol and pyrazinamide [154,155]. The results showed that Risorine provides more Rifampicin in blood and maintained higher blood levels on chronic therapy compared to conventional Rifampicin therapy, but with better safety profile, higher sputum conversion rate, and higher cure rate [155]. Bedada and Boga [177] investigated the effect of piperine to pharmacokinetics of chlorzoxazone in healthy volunteers and found significant interaction between these two compounds. This was observed trough increased $C_{\max }, A U C, T_{1 / 2}$ and decreased $K_{e l}$ and CL/F of chlozoxazone when administered with piperine. The same authors [179] found very similar effect of piperine intake to bioavailibility of fexofenadine, where piperine treatment significantly increased $C_{\max }$ of fexofenadine and AUC time curve, as well as decreased CL/F of this drug. A 3-fold increase in $\mathrm{C}_{\max }$ and 1.5-fold increase in AUC were found for tetrahydrocannabinol, while a 4-fold increase in $C_{\max }$ and a 2.2-fold increase in AUC were observed for cannabidiol when co-administered with piperine [159].

\subsection{Clinical Trials on Piperine Effect on Human Health}

\subsubsection{Effect of Piperine on the Digestive Tract}

Pure piperine was found to be very beneficial in the treatment of dysphagia, as shown in the trial of Rofes et al. [180], performed on 40 dysphagia patients, randomized into two groups receiving two doses of piperine $(150 \mu \mathrm{M}$ or $1 \mathrm{mM})$. Piperine improved the safety of swallow by reducing the prevalence of unsafe swallows, the severity score of penetration-aspiration scale, and shortened the time to laryngeal vestibule closure in a dose-dependent manner (Table 2). 
Table 2. Clinical trials on the effect of piperine on other human conditions.

\begin{tabular}{|c|c|c|c|c|}
\hline Condition/Effect of Piperine & No of Patients/Study Design & Trial Length & Treatment, Dose and Formulation of Piperine & Ref. \\
\hline $\begin{array}{l}\text { Higher repigmentation rate in piperine group at time intervals of 1,2, } \\
\text { and } 3 \text { months after the treatment } \\
\begin{array}{l}\text { Side effects occurred in } 45 \% \text { of the piperine treated patients (burning } \\
\text { sensations on their skin areas and/or redness). Both side effects were } \\
\text { mild and temporary. }\end{array}\end{array}$ & $\begin{array}{l}63 \text { patients with facial vitiligo } \\
\text { double-blind, placebo-controlled, } \\
\text { randomized clinical trial }\end{array}$ & 3 months & $\begin{array}{l}\text { Group 1: topical piperine solution + NB-UVB phototherapy every } \\
\text { other day for } 3 \text { months } \\
\text { Group 2: placebo + received NB-UVB phototherapy every other day } \\
\text { for } 3 \text { months. } \\
\text { Piperine solution (1\%) was prepared by dissolving the piperine in a } \\
\text { solvent mixture (dimethyl sulfoxide:isopropyl alcohol:glycerol; } \\
\text { 20:20:60; \%w/v) }\end{array}$ & [182] \\
\hline 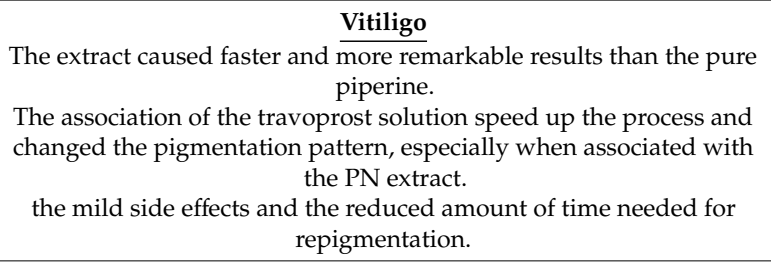 & 3 human subjects with vitiligo & 3 months & $\begin{array}{l}\text { Piper nigrum extract (PN) and pure piperine were integrated in two } \\
\text { different ointments. } \\
\text { Each subject treated } 9 \text { areas: } 3 \text { using the extract, } 3 \text { using pure piperine, } \\
1 \text { using travoprost solution } 40 \mu \mathrm{g} / \mathrm{mL} \text {, and } 2 \text { using an association of } \\
\text { travoprost (prostaglandin F } 2 \alpha \text { analogue) solution and our products. } \\
\text { The ointments were applied once a day, in the evening. }\end{array}$ & [183] \\
\hline $\begin{array}{l}\text { Swallow response } \\
\text { Piperine improved the safety of swallow by: } \\
\text { 1. reducing the prevalence of unsafe swallows (by } 34.48 \% \text { ) at } 150 \mu \mathrm{M} \\
\text { and by } 57.19 \% \text { at } 1 \mathrm{mM} \text {, and the severity score of the } \\
\text { penetration-aspiration scale from } 3.25 \text { to } 1.85 ; \\
\text { 2. shortening the time to laryngeal vestibule closure from } 0.366 \text { to } \\
0.270 \mathrm{~s} \text { with } 150 \mu \mathrm{M} \text { piperine and from } 0.380 \text { to } 0.306 \mathrm{~s} \text { with } \\
1 \mathrm{mM} \text { piperine }\end{array}$ & $\begin{array}{l}40 \text { dysphagic patients } \\
\text { randomized, double-blind, } \\
\text { interventional, controlled study, } \\
\text { with a pre- and } \\
\text { post-treatment design }\end{array}$ & 1 month & $\begin{array}{l}\text { Group } 1 \text { received } 150 \mu \mathrm{M} \text { of piperine } \\
\text { Group } 2 \text { received } 1 \mathrm{mM} \text { of piperine }\end{array}$ & [180] \\
\hline $\begin{array}{l}\text { Satiety and thermogenesis } \\
\text { The supplemented group experienced a significantly greater increase } \\
\text { in in their sensation of satiety and resting energy expenditure }\end{array}$ & $\begin{array}{l}37 \text { overweight adults } \\
\text { a randomized double-blind } \\
\text { placebo-controlled trial }\end{array}$ & A single dose & $\begin{array}{l}\text { Each subject received two capsules of a dietary supplement } \\
\text { (capsaicinoids, epigallocatechin gallate, piperin, and l-carnitine) or a } \\
\text { placebo that was identical in appearance. } \\
\text { After the meal, satiety, resting energy expenditure (REE), respiratory } \\
\text { quotient, glucagon-like peptide-1 (GLP-1), free fatty acids (FFA) and } \\
\text { glycerol release were measured. }\end{array}$ & [184] \\
\hline $\begin{array}{l}\text { Gingivitis } \\
\text { The group receiving antioxidant therapy showed higher reduction of } \\
\text { the plaque index, gingival index and probing pocket depth }\end{array}$ & $\begin{array}{l}60 \text { participants with chronic } \\
\text { generalized gingivitis } \\
\text { a randomized control clinical study }\end{array}$ & 3 weeks & $\begin{array}{l}\text { Group I-350 mg/day antioxidant therapy (curcumin } 300 \mathrm{mg}+ \\
\text { piperine } 5 \mathrm{mg}+\text { lycopene } 10 \mathrm{mg} \text { ) along with SRP twice a day } \\
\text { Group II-SRP alone }\end{array}$ & [181] \\
\hline $\begin{array}{l}\text { Systemic oxidative stress and accompanying symptoms } \\
\text { a greater effect of curcuminoids-piperine combination compared to } \\
\text { placebo in elevating GSH, reducing MDA and improving CAT and } \\
\text { SGRQ (total and subscale) scores }\end{array}$ & $\begin{array}{l}89 \text { subjects } \\
\text { a randomized double-blind } \\
\text { placebo-controlled trial }\end{array}$ & 4 weeks & $\begin{array}{l}\text { subjects were randomly allocated to either curcuminoids ( } 1500 \\
\mathrm{mg} / \text { day })+ \text { piperine }(15 \mathrm{mg} / \text { day) combination or placebo. }\end{array}$ & [185] \\
\hline $\begin{array}{l}\text { Metabolic syndrome } \\
\text { Supplementation with curcuminoid-piperine combination } \\
\text { significantly improved serum SOD activities and reduced MDA and } \\
\text { CRP concentrations compared with placebo. }\end{array}$ & $\begin{array}{l}117 \text { subjects with MetS, } \\
\text { a randomized double-blind } \\
\text { placebo-controlled trial }\end{array}$ & 8 weeks & $\begin{array}{c}\text { Group 1-a daily dose of curcuminoids }(1 \mathrm{~g}) \text { supplemented with } \\
\text { piperine }(10 \mathrm{mg}) \\
\text { Group 2-placebo }\end{array}$ & [186] \\
\hline
\end{tabular}


Another study investigated the efficacy of systemically administered piperine combined with lycopene and curcumin (PLC) as an adjunct to scaling and root planing (SRD) in patients with moderate gingivitis [181]. A reduction of the clinical parameters was higher in the test group receiving SRD + PLC than the control group (SRD alone) after 21 days of the treatment.

\subsubsection{Vitiligo}

Two clinical trials have evaluated the effect of topical piperine on vitiligo treatment and found positive effects (Table 2). In patients with facial vitiligo, topical treatment with piperine combined with narrowband UVB (NB-UVB) therapy resulted in significantly higher repigmentation rate at time intervals of 1,2, and 3 months after treatment than in the control group [182]. In another study [183], a Piper nigrum fruit extract and pure piperine were integrated into different ointments and applied for 12 weeks to different skin areas of the vitiligo patients. The results showed a higher efficiency of the black pepper extract than that of the pure piperine. In a study of Donata et al. [187], an Ayurvedic preparation consisting of dried ginger, black pepper, pippali and leadwort root fermented in cow's urine was given twice daily before a meal to vitiligo patients as a drink. After six months of the treatment, only $40 \%$ of the patients showed relief of symptoms.

\subsubsection{Other Conditions}

Piperine has been applied as a bioavailability enhancer of curcuminoid preparations in several clinical studies (Table 2). In subjects suffering from chronic pulmonary complications due to sulfur mustard exposure and receiving a standard respiratory therapy, treatment with combination of piperine and curcuminoids for 4 weeks significantly improved St. George respiratory Questionnaire (SGRQ) and COPD Assessment Test (CAT) (total and subscale) scores, elevated GSH and reduced MDA, thus improving general health-related quality of life (HRQoL) [185]. Panahi et al. [186] studied the effectiveness of supplementation with a curcuminoid preparation containing piperine on measures of oxidative stress and inflammation in patients with metabolic syndrome. The results in the test group demonstrated improved serum SOD activities and reduced MDA and C-reactive protein (CRP) concentrations compared with placebo. With the aim of determining the impact of a single consumption of a CBFI (capsaicinoids, epigallocatechin gallate, piperin, and l-carnitine) on satiety, resting energy expenditure (REE), respiratory quotient, glucagon-like peptide-1 (GLP-1), free fatty acids (FFA) and glycerol release, Rondanelli et al. [188] conducted a clinical trial on 37 overweight adults, and the results showed improvement in all investigated parameters.

\subsubsection{Clinical Trials on Black and Red Pepper}

There have been many other human clinical trials that investigated the effect of black and/or red pepper (but not pure piperine), either as a food ingredient, in capsules, or in the form of essential oil. One of the early clinical trials [189] investigated the effect of red and black pepper consumption on the gastric mucosa. A single dose of the test meals containing red pepper (0.1-1.5 g) or black pepper (1.5 g) was administered (intragastric) to healthy human volunteers, while aspirin $(655 \mathrm{mg})$ and distilled water were used as positive and negative controls, respectively. It was concluded that a single dose had negative effects on gastric mucosa, causing a significant increase in gastric exfoliation and even mucosal micro bleeding. Therefore, the investigated spices should be used with caution due to negative effects on gastric mucosa, which are comparable to those of aspirin. In a trial of Vazquez-Olivencia et al. [190], the effects of red pepper and black pepper on small intestinal peristalsis were investigated by measuring orocecal transit time (OCTT). When gelatine capsules containing black or red pepper were given to the healthy subjects, OCTT increased significantly after red pepper consumption, while black pepper failed to show statistically significant efficacy.

Rose and Behm [191] reported the beneficial effect of vapor from the essential oil of black pepper (BPO) as a cigarette substitute, where the craving for cigarettes, negative affect and somatic symptoms of anxiety were alleviated with a high degree of significance. Another trial evaluated the effect of 
olfactory stimulation with volatile BPO on risk factors for pneumonia and found improvement of the reflexive swallowing movement in poststroke patients with dysphagia, regardless of their level of consciousness or physical and mental status [192]. In pediatric patients receiving long-term enteral nutrition due to neurological disorders, olfactory stimulation with $100 \mu \mathrm{L}$ of BPO for three months improved and facilitated oral intake [193]. Some studies reported a lack of black pepper effect on the investigated parameters. After receiving a single brunch meal containing $1.3 \mathrm{~g}$ of pepper, there was no statistical significance related to postprandial diet-induced thermogenesis, as well as in appetite or food intake in young male participants [194]. Investigation of the impact of $0.5 \mathrm{~g}$ of black pepper as a part of a meal on 24-hour energy expenditure, respiratory quotient, and biochemical markers of metabolism and satiety showed lack of effect to energy expenditure in overweight post-menopausal women [184]. Also, Lindheimer et al. [195] reported a lack of activity of a single dose of black pepper capsules $(2.0 \mathrm{~g})$ on short-term improvements in sustained attention, motivation to perform cognitive tasks, or feelings of mental energy and fatigue in young adults with low energy.

\section{Conclusions}

The scientific evidence provided supports the traditional utilization of various pepper species containing high amounts of piperine. In vitro and in vivo data provided deep insight into the mechanisms of piperine action, which are related to its antioxidant and anti-inflammatory efficacy, together with its ability to interfere with several molecular signaling pathways. Its antitumor potential, demonstrated through its apoptotic effect on many cancer types, should be further investigated, especially in the form of human clinical trials, since such data do not exist. Also, due to some negative effects on the liver and on male fertility when given in high doses, future studies should focus on finding a safe therapeutic dose for pure piperine, since it represents a promising agent for the treatment of many human disorders. All these facts point to the therapeutic potential of piperine and the need to incorporate this compound into general health-enhancing medical formulations (especially those containing other well established antioxidants), as well as into those that could be used as adjunctive therapy in order to enhance the bioavailability of various (chemo)therapeutic drugs.

Author Contributions: All authors (Z.S.-R., M.P., M.D., A.A., N.V.A.K., B.S., W.C.C., and J.S.-R.) contributed equally to this work. Z.S.-R., M.P, W.C.C., and J.S.-R. critically reviewed the manuscript. All the authors read and approved the final manuscript.

Funding: This research received no external funding.

Acknowledgments: This research was funded by the Ministry of Education, Science and Technological Development of Serbia [Grant No. 172061 and 172036].

Conflicts of Interest: The authors declare no conflict of interest.

\section{References}

1. Chopra, B.; Dhingra, A.K.; Kapoor, R.P.; Prasad, D.N. Piperine and its various physicochemical and biological aspects: A review. Open Chem. J. 2017, 3, 75-96. [CrossRef]

2. Gorgani, L.; Mohammadi, M.; Najafpour, G.D.; Nikzad, M. Piperine-The bioactive compound of black pepper: From isolation to medicinal formulations. Compr. Rev. Food Sci. Food Saf. 2017, 16, 124-140. [CrossRef]

3. Majeed, M.; Labs, S.; Majeed, M. The medical uses of pepper. Int. Pepper News 2015, 25, $23-31$.

4. Meghwal, M.; Goswami, T.K. Chemical composition, nutritional, medicinal and functional properties of black pepper: A review. Open Access Sci. Rep. 2012, 1, 1-5.

5. Damanhouri, Z.A. A review on therapeutic potential of Piper nigrum L. (black pepper): The king of spices. Med. Aromat. Plants 2014, 3, 161. [CrossRef]

6. Salehi, B.; Zakaria, Z.A.; Gyawali, R.; Ibrahim, S.A.; Rajkovic, J.; Shinwari, Z.K.; Khan, T.; Sharifi-Rad, J.; Ozleyen, A.; Turkdonmez, E.; et al. Piper species: A comprehensive review on their phytochemistry, biological activities and applications. Molecules 2019, 24, 1364. [CrossRef] [PubMed] 
7. Mhaske, D.B.; Sreedharan, S.; Mahadik, K.R. Role of piperine as an effective bioenhancer in drug absorption. Pharm. Anal. Acta 2018, 9, 591.

8. Thiel, A.; Buskens, C.; Woehrle, T.; Etheve, S.; Schoenmakers, A.; Fehr, M.; Beilstein, P. Black pepper constituent piperine: Genotoxicity studies in vitro and in vivo. Food Chem. Toxicol. 2014, 66, 350-357. [CrossRef] [PubMed]

9. Bezerra, D.P.; de Castro, F.O.; Alves, A.P.N.N.; Pessoa, C.; de Moraes, M.O.; Silveira, E.R.; Lima, M.A.S.; Elmiro, F.J.M.; de Alencar, N.M.N.; Mesquita, R.O.; et al. In vitro and in vivo antitumor effect of 5-FU combined with piplartine and piperine. J. Appl. Toxicol. 2008, 28, 156-163. [CrossRef]

10. Bernardo, A.R.; da Rocha, J.D.B.; de Lima, M.E.F.; Ricardo, D.D.; da Silva, L.H.P.; Peçanha, L.M.T.; Danelli, M.D.G.M. Modulating effect of the piperine, the main alkaloid from Piper nigrum Linn., on murine B lymphocyte function. Braz. J. Vet. Med. 2015, 37, 209-216.

11. Lee, Y.M.; Choi, J.H.; Min, W.K.; Han, J.K.; Oh, J.W. Induction of functional erythropoietin and erythropoietin receptor gene expression by gamma-aminobutyric acid and piperine in kidney epithelial cells. Life Sci. 2018, 215, 207-215. [CrossRef] [PubMed]

12. Aswar, U.; Shintre, S.; Chepurwar, S.; Aswar, M. Antiallergic effect of piperine on ovalbumin-induced allergic rhinitis in mice. Pharm. Biol. 2015, 53, 1358-1366. [CrossRef] [PubMed]

13. Kim, S.-H.; Lee, Y.-C. Piperine inhibits eosinophil infiltration and airway hyperresponsiveness by suppressing T cell activity and Th2 cytokine production in the ovalbumin-induced asthma model. J. Pharm. Pharmacol. 2009, 61, 353-359. [CrossRef] [PubMed]

14. Rauscher, F.M.; Sanders, R.A.; Watkins, J.B. Effects of piperine on antioxidant pathways in tissues from normal and streptozotocin-induced diabetic rats. J. Biochem. Mol. Toxicol. 2000, 14, 329-334. [CrossRef]

15. BrahmaNaidu, P.; Nemani, H.; Meriga, B.; Mehar, S.K.; Potana, S.; Ramgopalrao, S. Mitigating efficacy of piperine in the physiological derangements of high fat diet induced obesity in Sprague Dawley rats. Chem. Biol. Interact. 2014, 221, 42-51. [CrossRef] [PubMed]

16. Kharbanda, C.; Alam, M.S.; Hamid, H.; Javed, K.; Bano, S.; Ali, Y.; Dhulap, A.; Alam, P.; Pasha, M.A.Q. Novel piperine derivatives with antidiabetic effect as PPAR- $\gamma$ agonists. Chem. Biol. Drug Des. 2016, 88, 354-362. [CrossRef]

17. Atal, S.; Agrawal, R.P.; Vyas, S.; Phadnis, P.; Rai, N. Evaluation of the effect of piperine per se on blood glucose level in alloxan-induced diabetic mice. Acta Pol. Pharm. 2012, 69, 965-969.

18. Atal, S.; Atal, S.; Vyas, S.; Phadnis, P. Bio-enhancing effect of piperine with metformin on lowering blood glucose level in alloxan induced diabetic mice. Pharmacogn. Res. 2016, 8, 56-60. [CrossRef]

19. Veeresham, C.; Sujatha, S.; Rani, T.S. Effect of piperine on the pharmacokinetics and pharmacodynamics of glimepiride in normal and streptozotocin-induced diabetic rats. Nat. Prod. Commun. 2012, 7, 1283-1286. [CrossRef]

20. Jwa, H.; Choi, Y.; Park, U.-H.; Um, S.-J.; Yoon, S.K.; Park, T. Piperine, an LXR $\alpha$ antagonist, protects against hepatic steatosis and improves insulin signaling in mice fed a high-fat diet. Biochem. Pharmacol. 2012, 84, 1501-1510. [CrossRef]

21. Park, U.-H.; Jeong, H.-S.; Jo, E.-Y.; Park, T.; Yoon, S.K.; Kim, E.-J.; Jeong, J.-C.; Um, S.-J. Piperine, a component of black pepper, inhibits adipogenesis by antagonizing PPAR $\gamma$ activity in 3T3-L1 cells. J. Agric. Food Chem. 2012, 60, 3853-3860. [CrossRef] [PubMed]

22. Reen, R.K.; Jamwal, D.S.; Taneja, S.C.; Koul, J.L.; Dubey, R.K.; Wiebel, F.J.; Singh, J. Impairment of UDP-glucose dehydrogenase and glucuronidation activities in liver and small intestine of rat and guinea pig in vitro by piperine. Biochem. Pharmacol. 1993, 46, 229-238. [CrossRef]

23. Subramaniam, R.; Kumar, V.; Nalini, N. Lipid-lowering efficacy of piperine from Piper nigrum L. in high-fat diet and antithyroid drug-induced hypercholesterolemic rats. J. Food Biochem. 2006, 30, 405-421.

24. Sabina, E.P.; Souriyan, A.D.H.; Jackline, D.; Rasool, M.K. Piperine, an active ingredient of black pepper attenuates acetaminophen-induced hepatotoxicity in mice. Asian Pac. J. Trop. Med. 2010, 3, 971-976. [CrossRef]

25. Sudjarwo, S.A.; Eraiko, K.; Sudjarwo, G.W.K. Koerniasari Protective effects of piperine on lead acetate induced-nephrotoxicity in rats. Iran. J. Basic Med. Sci. 2017, 20, 1227-1231.

26. Verma, N.; Bal, S.; Gupta, R.; Aggarwal, N.; Yadav, A. Antioxidative effects of piperine against cadmium-induced oxidative stress in cultured human peripheral blood lymphocytes. J. Diet. Suppl. 2018, 9, 1-12. [CrossRef] 
27. Vijayakumar, R.S.; Nalini, N. Efficacy of piperine, an alkaloidal constituent from Piper nigrum on erythrocyte antioxidant status in high fat diet and antithyroid drug induced hyperlipidemic rats. Cell Biochem. Funct. 2006, 24, 491-498. [CrossRef]

28. Elkady, A.; Tawfik, S.S. Anti-inflammatory role of piperine against rat lung tissue damage induced by gamma-rays. Int. J. Radiat. Res. 2018, 16, 75-84.

29. Bae, G.-S.; Kim, M.-S.; Jung, W.-S.; Seo, S.-W.; Yun, S.-W.; Kim, S.G.; Park, R.-K.; Kim, E.-C.; Song, H.-J.; Park, S.-J. Inhibition of lipopolysaccharide-induced inflammatory responses by piperine. Eur. J. Pharmacol. 2010, 642, 154-162. [CrossRef]

30. Chen, W.S.; Jie, A.; Li, J.J.; Hong, L.; Xing, Z.B.; Li, C.Q. Piperine attenuates lipopolysaccharide (LPS)-induced inflammatory responses in BV2 microglia. Int. Immunopharmacol. 2017, 42, 44-48.

31. Chuchawankul, S.; Khorana, N.; Poovorawan, Y. Piperine inhibits cytokine production by human peripheral blood mononuclear cells. Genet. Mol. Res. 2012, 11, 617-627. [CrossRef] [PubMed]

32. Ying, X.; Yu, K.; Chen, X.; Chen, H.; Hong, J.; Cheng, S.; Peng, L. Piperine inhibits LPS induced expression of inflammatory mediators in RAW 264.7 cells. Cell. Immunol. 2013, 285, 49-54. [CrossRef] [PubMed]

33. Li, Y.; Li, K.; Hu, Y.; Xu, B.; Zhao, J. Piperine mediates LPS induced inflammatory and catabolic effects in rat intervertebral disc. Int. J. Clin. Exp. Pathol. 2015, 8, 6203-6213. [PubMed]

34. Bang, J.S.; Oh, D.H.; Choi, H.M.; Sur, B.-J.; Lim, S.-J.; Kim, J.Y.; Yang, H.-I.; Yoo, M.C.; Hahm, D.-H.; Kim, K.S. Anti-inflammatory and antiarthritic effects of piperine in human interleukin $1 \beta$-stimulated fibroblast-like synoviocytes and in rat arthritis models. Arthritis Res. Ther. 2009, 11, R49. [CrossRef] [PubMed]

35. Dong, Y.; Huihui, Z.; Li, C. Piperine inhibit inflammation, alveolar bone loss and collagen fibers breakdown in a rat periodontitis model. J. Periodontal Res. 2015, 50, 758-765. [CrossRef] [PubMed]

36. Son, D.J.; Akiba, S.; Hong, J.T.; Yun, Y.P.; Hwang, S.Y.; Park, Y.H.; Lee, S.E. Piperine inhibits the activities of platelet cytosolic phospholipase $\mathrm{A}_{2}$ and thromboxane $\mathrm{A}_{2}$ synthase without affecting cyclooxygenase-1 activity: Different mechanisms of action are involved in the inhibition of platelet aggregation and macrophage inflammatory response. Nutrients 2014, 6, 3336-3352. [PubMed]

37. D'cruz, S.C.; Mathur, P.P. Effect of piperine on the epididymis of adult male rats. Asian J. Androl. 2005, 7, 363-368. [CrossRef]

38. Bajad, S.; Bedi, K.L.; Singla, A.K.; Johri, R.K. Piperine inhibits gastric emptying and gastrointestinal transit in rats and mice. Planta Med. 2001, 67, 176-179. [CrossRef]

39. Sabina, E.P.; Nasreen, A.; Vedi, M.; Rasool, M. Analgesic, antipyretic and ulcerogenic effects of piperine: An active ingredient of pepper. J. Pharm. Sci. Res. 2013, 5, 203-206.

40. Bai, Y.F.; Xu, H. Protective action of piperine against experimental gastric ulcer. Acta Pharmacol. Sin. 2000, 21, 357-359.

41. Bajaj, S. Anti-mutagenic activity of piperine against food mutagens. Indian Drugs 2003, 40, 358-362.

42. Wongpa, S.; Himakoun, L.; Soontornchai, S.; Temcharoen, P. Antimutagenic effects of piperine on cyclophosphamide-induced chromosome aberrations in rat bone marrow cells. Asian Pac. J. Cancer Prev. 2007, 8, 623-627. [PubMed]

43. Khandelwal, S.; Pathak, N.; Singh, M. Protective role of piperine against cadmium induced hepatic and renal toxocity. Toxicol. Int. 2008, 15, 85-89.

44. Abo-Zeid, M.A.M.; Farghaly, A.A. The anti-mutagenic activity of piperine against mitomycine $\mathrm{C}$ induced sister chromatid exchanges and chromosomal aberrations in mice. Nat. Sci. 2009, 7, 72-78.

45. Reen, R.K.; Wiebel, F.J.; Singh, J. Piperine inhibits aflatoxin B1-induced cytotoxicity and genotoxicity in V79 Chinese hamster cells genetically engineered to express rat cytochrome P4502B1. J. Ethnopharmacol. 1997, 58, 165-173. [CrossRef]

46. Kumar, A.; Sasmal, D.; Sharma, N. Immunomodulatory role of piperine in deltamethrin induced thymic apoptosis and altered immune functions. Environ. Toxicol. Pharmacol. 2015, 39, 504-514. [CrossRef] [PubMed]

47. Do, M.T.; Kim, H.G.; Choi, J.H.; Khanal, T.; Park, B.H.; Tran, T.P.; Jeong, T.C.; Jeong, H.G. Antitumor efficacy of piperine in the treatment of human HER2-overexpressing breast cancer cells. Food Chem. 2013, 141, 2591-2599. [CrossRef]

48. Greenshields, A.L.; Doucette, C.D.; Sutton, K.M.; Madera, L.; Annan, H.; Yaffe, P.B.; Knickle, A.F.; Dong, Z.; Hoskin, D.W. Piperine inhibits the growth and motility of triple-negative breast cancer cells. Cancer Lett. 2015, 357, 129-140. [CrossRef] [PubMed] 
49. Kakarala, M.; Brenner, D.E.; Korkaya, H.; Cheng, C.; Tazi, K.; Ginestier, C.; Liu, S.; Dontu, G.; Wicha, M.S. Targeting breast stem cells with the cancer preventive compounds curcumin and piperine. Breast Cancer Res. Treat. 2010, 122, 777-785. [CrossRef]

50. Abdelhamed, S.; Yokoyama, S.; Refaat, A.; Ogura, K.; Yagita, H.; Awale, S.; Saiki, I. Piperine enhances the efficacy of TRAIL-based therapy for triple-negative breast cancer cells. Anticancer Res. 2014, 34, 1893-1899.

51. Lai, L.H.; Fu, Q.H.; Liu, Y.; Jiang, K.; Guo, Q.M.; Chen, Q.Y.; Yan, B.; Wang, Q.Q.; Shen, J.G. Piperine suppresses tumor growth and metastasis in vitro and in vivo in a $4 \mathrm{~T} 1$ murine breast cancer model. Acta Pharmacol. Sin. 2012, 33, 523-530. [CrossRef] [PubMed]

52. Umadevi, P.; Deepti, K.; Venugopal, D.V.R. Synthesis, anticancer and antibacterial activities of piperine analogs. Med. Chem. Res. 2013, 22, 5466-5471. [CrossRef]

53. Lin, Y.; Xu, J.; Liao, H.; Li, L.; Pan, L. Piperine induces apoptosis of lung cancer A549 cells via p53-dependent mitochondrial signaling pathway. Tumour Biol. 2014, 35, 3305-3310. [CrossRef] [PubMed]

54. Selvendiran, K.; Banu, S.M.; Sakthisekaran, D. Protective effect of piperine on benzo(a)pyrene-induced lung carcinogenesis in Swiss albino mice. Clin. Chim. Acta 2004, 350, 73-78. [CrossRef] [PubMed]

55. Chu, C.Y.; Chang, J.P.; Wang, C.J. Modulatory effect of piperine on benzo[a]pyrene cytotoxicity and DNA adduct formation in V-79 lung fibroblast cells. Food Chem. Toxicol. 1994, 32, 373-377. [CrossRef]

56. Selvendiran, K.; Banu, S.M.; Sakthisekaran, D. Oral supplementation of piperine leads to altered phase II enzymes and reduced DNA damage and DNA-protein cross links in Benzo(a)pyrene induced experimental lung carcinogenesis. Mol. Cell. Biochem. 2005, 268, 141-147. [CrossRef] [PubMed]

57. Selvendiran, K.; Thirunavukkarasu, C.; Singh, J.P.V.; Padmavathi, R.; Sakthisekaran, D. Chemopreventive effect of piperine on mitochondrial TCA cycle and phase-I and glutathione-metabolizing enzymes in benzo(a)pyrene induced lung carcinogenesis in Swiss albino mice. Mol. Cell. Biochem. 2005, 271, 101-106. [CrossRef] [PubMed]

58. Pradeep, C.R.; Kuttan, G. Effect of piperine on the inhibition of lung metastasis induced B16F-10 melanoma cells in mice. Clin. Exp. Metastasis 2002, 19, 703-708. [CrossRef] [PubMed]

59. Ba, Y.; Malhotra, A. Potential of piperine in modulation of voltage-gated $\mathrm{K}^{+}$current and its influences on cell cycle arrest and apoptosis in human prostate cancer cells. Eur. Rev. Med. Pharmacol. Sci. 2018, 22, 8999-9011. [PubMed]

60. Ouyang, D.; Zeng, L.; Pan, H.; Xu, L.; Wang, Y.; Liu, K.; He, X. Piperine inhibits the proliferation of human prostate cancer cells via induction of cell cycle arrest and autophagy. Food Chem. Toxicol. 2013, 60, 424-430. [CrossRef] [PubMed]

61. Samykutty, A.; Shetty, A.V.; Dakshinamoorthy, G.; Bartik, M.M.; Johnson, G.L.; Webb, B.; Zheng, G.; Chen, A.; Kalyanasundaram, R.; Munirathinam, G. Piperine, a bioactive component of pepper spice exerts therapeutic effects on androgen dependent and androgen independent prostate cancer cells. PLoS ONE 2013, 8, e65889. [CrossRef] [PubMed]

62. Zeng, Y.; Yang, Y. Piperine depresses the migration progression via downregulating the Akt/mTOR/MMP-9 signaling pathway in DU145 cells. Mol. Med. Rep. 2018, 17, 6363-6370. [CrossRef] [PubMed]

63. Han, S.-Z.; Liu, H.-X.; Yang, L.-Q.; Cui, L.; Xu, Y. Piperine (PP) enhanced mitomycin-C (MMC) therapy of human cervical cancer through suppressing Bcl-2 signaling pathway via inactivating STAT3/NF-kB. Biomed. Pharmacother. 2017, 96, 1403-1410. [CrossRef] [PubMed]

64. Si, L.; Yang, R.; Lin, R.; Yang, S. Piperine functions as a tumor suppressor for human ovarian tumor growth via activation of JNK/p38 MAPK-mediated intrinsic apoptotic pathway. Biosci. Rep. 2018, 38, BSR20180503. [CrossRef] [PubMed]

65. Krishnakumar, N.; Manoharan, S.; Palaniappan, P.R.; Venkatachalam, P.; Manohar, M.G.A. Chemopreventive efficacy of piperine in 7,12-dimethyl benz [a] anthracene (DMBA)-induced hamster buccal pouch carcinogenesis: An FT-IR study. Food Chem. Toxicol. 2009, 47, 2813-2820. [CrossRef] [PubMed]

66. Shin, S.A.; Lee, H.N.; Choo, G.S.; Kim, S.J.; Kim, H.J.; Park, Y.S.; Park, B.K.; Kim, B.S.; Kim, S.K.; Lee, H.J.; et al. Induction of apoptosis and inhibition of growth in human gastric cancer by piperine. J. Korean Soc. Food Sci. Nutr. 2016, 45, 1589-1594. [CrossRef]

67. Xia, Y.; Khoi, P.N.; Yoon, H.J.; Lian, S.; Joo, Y.E.; Chay, K.O.; Kim, K.K.; Jung, D.Y. Piperine inhibits IL-1 $\beta$-induced IL-6 expression by suppressing p38 MAPK and STAT3 activation in gastric cancer cells. Mol. Cell. Biochem. 2015, 398, 147-156. [CrossRef] 
68. Kim, E.J.; Park, H.; Shin, M.; Shin, H.K.; Yoon Park, J.H. Induction of apoptosis in HT-29 human colon cancer cells by the pepper component piperine. J. Korean Soc. Food Sci. Nutr. 2009, 38, 442-450. [CrossRef]

69. Yaffe, P.B.; Power Coombs, M.R.; Doucette, C.D.; Walsh, M.; Hoskin, D.W. Piperine, an alkaloid from black pepper, inhibits growth of human colon cancer cells via G1 arrest and apoptosis triggered by endoplasmic reticulum stress. Mol. Carcinog. 2015, 54, 1070-1085. [CrossRef]

70. Yaffe, P.B.; Doucette, C.D.; Walsh, M.; Hoskin, D.W. Piperine impairs cell cycle progression and causes reactive oxygen species-dependent apoptosis in rectal cancer cells. Exp. Mol. Pathol. 2013, 94, 109-114. [CrossRef]

71. Kaur, H.; He, B.; Zhang, C.; Rodriguez, E.; Hage, D.S.; Moreau, R. Piperine potentiates curcumin-mediated repression of $\mathrm{mTORC1}$ signaling in human intestinal epithelial cells: Implications for the inhibition of protein synthesis and TNF $\alpha$ signaling. J. Nutr. Biochem. 2018, 57, 276-286. [CrossRef] [PubMed]

72. Pradeep, C.R.; Kuttan, G. Piperine is a potent inhibitor of nuclear factor-kappaB (NF-kappaB), c-Fos, CREB, ATF-2 and proinflammatory cytokine gene expression in B16F-10 melanoma cells. Int. Immunopharmacol. 2004, 4, 1795-1803. [CrossRef] [PubMed]

73. Rafiq, R.A.; Ganai, B.A.; Tasduq, S.A. Piperine promotes ultraviolet (UV)-B-induced cell death in B16F10 mouse melanoma cells through modulation of major regulators of cell survival. RSC Adv. 2015, 5, 11884-11894. [CrossRef]

74. Rao, V.R.S.; Suresh, G.; Rao, R.R.; Babu, K.S.; Chashoo, G.; Saxena, A.K.; Rao, J.M. Synthesis of piperine-amino acid ester conjugates and study of their cytotoxic activities against human cancer cell lines. Med. Chem. Res. 2012, 21, 38-46.

75. Huang, W.; Chen, Z.; Wang, Q.; Lin, M.; Wu, S.; Yan, Q.; Wu, F.; Yu, X.; Xie, X.; Li, G.; et al. Piperine potentiates the antidepressant-like effect of trans-resveratrol: Involvement of monoaminergic system. Metab. Brain Dis. 2013, 28, 585-595. [CrossRef] [PubMed]

76. Lee, S.A.; Hong, S.S.; Han, X.H.; Hwang, J.S.; Oh, G.J.; Lee, K.S.; Lee, M.K.; Hwang, B.Y.; Ro, J.S. Piperine from the fruits of Piper longum with inhibitory effect on monoamine oxidase and antidepressant-like activity. Chem. Pharm. Bull. 2005, 53, 832-835. [CrossRef] [PubMed]

77. Lee, S.A.; Hwang, J.S.; Han, X.H.; Lee, C.; Lee, M.H.; Choe, S.G.; Hong, S.S.; Lee, D.; Lee, M.K.; Hwang, B.Y. Methylpiperate derivatives from Piper longum and their inhibition of monoamine oxidase. Arch. Pharm. Res. 2008, 31, 679-683. [CrossRef]

78. Li, S.; Wang, C.; Li, W.; Koike, K.; Nikaido, T.; Wang, M.-W. Antidepressant-like effects of piperine and its derivative, antiepilepsirine. J. Asian Nat. Prod. Res. 2007, 9, 421-430. [CrossRef]

79. Mu, L.-H.; Wang, B.; Ren, H.-Y.; Liu, P.; Guo, D.-H.; Wang, F.-M.; Bai, L.; Guo, Y.-S. Synthesis and inhibitory effect of piperine derivates on monoamine oxidase. Bioorg. Med. Chem. Lett. 2012, 22, 3343-3348. [CrossRef]

80. Li, G.; Ruan, L.; Chen, R.; Wang, R.; Xie, X.; Zhang, M.; Chen, L.; Yan, Q.; Reed, M.; Chen, J.; et al. Synergistic antidepressant-like effect of ferulic acid in combination with piperine: Involvement of monoaminergic system. Metab. Brain Dis. 2015, 30, 1505-1514. [CrossRef]

81. Dalvi, R.R.; Dalvi, P.S. Comparison of the effects of piperine administered intragastrically and intraperitoneally on the liver and liver mixed-function oxidases in rats. Drug Metab. Drug Interact. 1991, 9, 23-30. [CrossRef]

82. Beltrán, L.R.; Dawid, C.; Beltrán, M.; Gisselmann, G.; Degenhardt, K.; Mathie, K.; Hofmann, T.; Hatt, H. The pungent substances piperine, capsaicin, 6-gingerol and polygodial inhibit the human two-pore domain potassium channels TASK-1, TASK-3 and TRESK. Front. Pharmacol. 2013, 4, 141. [CrossRef] [PubMed]

83. Chen, C.-Y.; Li, W.; Qu, K.-P.; Chen, C.-R. Piperine exerts anti-seizure effects via the TRPV1 receptor in mice. Eur. J. Pharmacol. 2013, 714, 288-294. [CrossRef] [PubMed]

84. Chen, X.; Ge, F.; Liu, J.; Bao, S.; Chen, Y.; Li, D.; Li, Y.; Huang, T.; Chen, X.; Zhu, Q.; et al. Diverged effects of piperine on testicular development: Stimulating leydig cell development but inhibiting spermatogenesis in rats. Front. Pharmacol. 2018, 9, 244. [CrossRef]

85. Gilhotra, N.; Dhingra, D. Possible involvement of GABAergic and nitriergic systems for antianxiety-like activity of piperine in unstressed and stressed mice. Pharmacol. Rep. 2014, 66, 885-891. [CrossRef] [PubMed]

86. Kang, A.H.; Won, S.M.; Park, S.S.; Kim, S.G.; Novak, R.F.; Kim, N.D. Piperine effects on the expression of p4502e1, p4502b and p4501a in rat. Xenobiotica 1994, 24, 1195-1204. [CrossRef] [PubMed]

87. Kazemi, M.; Pour Nasrollah, M.; Rezaei, M.; Jorsaraei, G.; Maliji, G.; Kazemi, S.; Zabihi, E.; Pouramir, M.; Moghadamnia, A.A. Effect of piperine pretreatment on biochemical profiles of acetaminophen-induced hepatotoxicity in rats. JBUMS 2012, 14, 7-14. 
88. Khajuria, A.; Thusu, N.; Yutshi, U.; Bedi, K.L. Antioxidant potential of piperine on oxidant induced alterations in rat intestinal lumen. Indian Drugs 1997, 34, 557-563.

89. Kim, D.-Y.; Kim, E.-J.; Jang, W.-G. Piperine induces osteoblast differentiation through AMPK-dependent Runx2 expression. Biochem. Biophys. Res. Commun. 2018, 495, 1497-1502. [CrossRef]

90. Kim, H.G.; Han, E.H.; Jang, W.-S.; Choi, J.H.; Khanal, T.; Park, B.H.; Tran, T.P.; Chung, Y.C.; Jeong, H.G. Piperine inhibits PMA-induced cyclooxygenase-2 expression through downregulating NF-kB, C/EBP and AP-1 signaling pathways in murine macrophages. Food Chem. Toxicol. 2012, 50, 2342-2348. [CrossRef]

91. Mao, K.; Lei, D.; Zhang, H.; You, C. Anticonvulsant effect of piperine ameliorates memory impairment, inflammation and oxidative stress in a rat model of pilocarpine-induced epilepsy. Exp. Ther. Med. 2017, 13, 695-700. [CrossRef] [PubMed]

92. Panda, S.; Kar, A. Piperine lowers the serum concentrations of thyroid hormones, glucose and hepatic $5^{\prime} \mathrm{D}$ activity in adult male mice. Horm. Metab. Res. 2003, 35, 523-526. [PubMed]

93. Sethi, K.K.; Sahoo, S.K.; Pichikala, J.N.; Suresh, P. Carbonic anhydrase I and II inhibition with natural products: Caffeine and piperine. J. Enzym. Inhib. Med. Chem. 2012, 27, 97-100. [CrossRef] [PubMed]

94. Choi, B.-M.; Kim, S.-M.; Park, T.-K.; Li, G.; Hong, S.-J.; Park, R.; Chung, H.-T.; Kim, B.-R. Piperine protects cisplatin-induced apoptosis via heme oxygenase-1 induction in auditory cells. J. Nutr. Biochem. 2007, 18, 615-622. [CrossRef] [PubMed]

95. Choi, S.; Choi, Y.; Choi, Y.; Kim, S.; Jang, J.; Park, T. Piperine reverses high fat diet-induced hepatic steatosis and insulin resistance in mice. Food Chem. 2013, 141, 3627-3635. [CrossRef] [PubMed]

96. Deepak, V.; Kruger, M.C.; Joubert, A.; Coetzee, M. Piperine alleviates osteoclast formation through the p38/c-Fos/NFATc1 signaling axis. Biofactors 2015, 41, 403-413. [CrossRef] [PubMed]

97. Doucette, C.D.; Greenshields, A.L.; Liwski, R.S.; Hoskin, D.W. Piperine blocks interleukin-2-driven cell cycle progression in CTLL-2 T lymphocytes by inhibiting multiple signal transduction pathways. Toxicol. Lett. 2015, 234, 1-12. [CrossRef]

98. Doucette, C.D.; Hilchie, A.L.; Liwski, R.; Hoskin, D.W. Piperine, a dietary phytochemical, inhibits angiogenesis. J. Nutr. Biochem. 2013, 24, 231-239. [CrossRef] [PubMed]

99. Doucette, C.D.; Rodgers, G.; Liwski, R.S.; Hoskin, D.W. Piperine from black pepper inhibits activation-induced proliferation and effector function of T lymphocytes. J. Cell. Biochem. 2015, 116, 2577-2588. [CrossRef]

100. Hou, X.-F.; Pan, H.; Xu, L.-H.; Zha, Q.-B.; He, X.-H.; Ouyang, D.-Y. piperine suppresses the expression of CXCL8 in lipopolysaccharide-activated SW480 and HT-29 cells via downregulating the mitogen-activated protein kinase pathways. Inflammation 2015, 38, 1093-1102. [CrossRef]

101. Kim, N.; Nam, M.; Kang, M.S.; Lee, J.O.; Lee, Y.W.; Hwang, G.S.; Kim, H.S. Piperine regulates UCP1 through the AMPK pathway by generating intracellular lactate production in muscle cells. Sci. Rep. 2017, 7, 41066. [CrossRef] [PubMed]

102. Kumar, S.; Singhal, V.; Roshan, R.; Sharma, A.; Rembhotkar, G.W.; Ghosh, B. Piperine inhibits TNF-alpha induced adhesion of neutrophils to endothelial monolayer through suppression of NF-kappaB and IkappaB kinase activation. Eur. J. Pharmacol. 2007, 575, 177-186. [CrossRef] [PubMed]

103. Lee, K.P.; Lee, K.; Park, W.-H.; Kim, H.; Hong, H. Piperine inhibits platelet-derived growth factor-BB-induced proliferation and migration in vascular smooth muscle cells. J. Med. Food 2015, 18, 208-215. [CrossRef] [PubMed]

104. Ren, C.; Liang, Z. Piperine alleviates lipopolysaccharide-induced inflammatory injury by down-regulating microRNA-127 in murine chondrogenic ATDC5 cells. Biomed. Pharmacother. 2018, 103, 947-954. [CrossRef] [PubMed]

105. Ma, Z.-G.; Yuan, Y.-P.; Zhang, X.; Xu, S.-C.; Wang, S.-S.; Tang, Q.-Z. Piperine attenuates pathological cardiac fibrosis via PPAR- $\gamma /$ AKT pathways. EBioMedicine 2017, 18, 179-187. [CrossRef] [PubMed]

106. Maeda, A.; Shirao, T.; Shirasaya, D.; Yoshioka, Y.; Yamashita, Y.; Akagawa, M.; Ashida, H. Piperine promotes glucose uptake through ROS-dependent activation of the CAMKK/AMPK signaling pathway in skeletal muscle. Mol. Nutr. Food Res. 2018, 62, e1800086. [CrossRef] [PubMed]

107. Zhang, J.; Zhu, X.; Li, H.; Li, B.; Sun, L.; Xie, T.; Zhu, T.; Zhou, H.; Ye, Z. Piperine inhibits proliferation of human osteosarcoma cells via G2/M phase arrest and metastasis by suppressing MMP-2/-9 expression. Int. Immunopharmacol. 2015, 24, 50-58. [CrossRef]

108. Gong, F.; Cui, L.; Zhang, X.; Zhan, X.; Gong, X.; Wen, Y. Piperine ameliorates collagenase-induced Achilles tendon injury in the rat. Connect. Tissue Res. 2018, 59, 21-29. [CrossRef] 
109. Liu, J.; Chen, M.; Wang, X.; Wang, Y.; Duan, C.; Gao, G.; Lu, L.; Wu, X.; Wang, X.; Yang, H. Piperine induces autophagy by enhancing protein phosphotase $2 \mathrm{~A}$ activity in a rotenone-induced Parkinson's disease model. Oncotarget 2016, 7, 60823-60843.

110. Mao, Q.-Q.; Huang, Z.; Ip, S.-P.; Xian, Y.-F.; Che, C.-T. Protective effects of piperine against corticosterone-induced neurotoxicity in PC12 cells. Cell. Mol. Neurobiol. 2012, 32, 531-537. [CrossRef]

111. Singh, S.; Jamwal, S.; Kumar, P. Neuroprotective potential of Quercetin in combination with piperine against 1-methyl-4-phenyl-1,2,3,6-tetrahydropyridine-induced neurotoxicity. Neural Regen. Res. 2017, 12, 1137-1144. [PubMed]

112. Fu, M.; Sun, Z.-H.; Zuo, H.-C. Neuroprotective effect of piperine on primarily cultured hippocampal neurons. Biol. Pharm. Bull. 2010, 33, 598-603. [CrossRef] [PubMed]

113. Unchern, S.; Nagata, K.; Saito, H.; Fukuda, J. Reduction of neurite extension by piperine, examined on hippocampal and septal neurons in serum-free cultures. Biol. Pharm. Bull. 1994, 17, 898-901. [CrossRef] [PubMed]

114. Khalili-Fomeshi, M.; Azizi, M.G.; Esmaeili, M.R.; Gol, M.; Kazemi, S.; Ashrafpour, M.; Moghadamnia, A.A.; Hosseinzadeh, S. Piperine restores streptozotocin-induced cognitive impairments: Insights into oxidative balance in cerebrospinal fluid and hippocampus. Behav. Brain Res. 2018, 337, 131-138. [CrossRef] [PubMed]

115. Hu, Y.; Liao, H.; Liu, P.; Guo, D.; Wang, Y. Antidepressant effects of piperine and its neuroprotective mechanism in rats. Zhong Xi Yi Jie He Xue Bao 2009, 7, 667-670. [CrossRef] [PubMed]

116. Bukhari, I.A.; Pivac, N.; Alhumayyd, M.S.; Mahesar, A.L.; Gilani, A.H. The analgesic and anticonvulsant effects of piperine in mice. J. Physiol. Pharmacol. 2013, 64, 789-794. [PubMed]

117. Piyachaturawat, P.; Glinsukon, T.; Toskulkao, C. Acute and subacute toxicity of piperine in mice, rats and hamsters. Toxicol. Lett. 1983, 16, 351-359. [CrossRef]

118. Rao, P.J.; Kolla, S.D.; Elshaari, F.; Elshaari, F.; Awamy, H.E.1.; Elfrady, M.; Singh, R.; Belkhier, A.; Srikumar, S.; Said, A.R.; et al. Effect of piperine on liver function of CF-1 albino mice. Infect. Disord. Drug Targets 2015, 15, 131-134. [CrossRef]

119. Allameh, A.; Saxena, M.; Biswas, G.; Raj, H.G.; Singh, J.; Srivastava, N. Piperine, a plant alkaloid of the piper species, enhances the bioavailability of aflatoxin B1 in rat tissues. Cancer Lett. 1992, 61, 195-199. [CrossRef]

120. Malini, T.; Manimaran, R.R.; Arunakaran, J.; Aruldhas, M.M.; Govindarajulu, P. Effects of piperine on testis of albino rats. J. Ethnopharmacol. 1999, 64, 219-225. [CrossRef]

121. Aldaly, Z.T.K. Antimicrobial activity of piperine purified from Piper nigrum. J. Basrah Res. 2010, 36, 54-61.

122. Hikal, D.M. Antibacterial activity of piperine and black pepper oil. Biosci. Biotechnol. Res. Asia 2018, 15, 877-880. [CrossRef]

123. Maitra, J. Synergistic effect of piperine, extracted from Piper nigrum, with ciprofloxacin on Escherichia coli, Bacillus subtilis. Pharm. Sin. 2017, 8, 29-34.

124. Jin, J.; Zhang, J.; Guo, N.; Feng, H.; Li, L.; Liang, J.; Sun, K.; Wu, X.; Wang, X.; Liu, M.; et al. The plant alkaloid piperine as a potential inhibitor of ethidium bromide efflux in Mycobacterium smegmatis. J. Med. Microbiol. 2011, 60, 223-229. [CrossRef] [PubMed]

125. Amperayani, K.R.; Kumar, K.N.; Parimi, U.D. Synthesis and in vitro and in silico antimicrobial studies of novel piperine-pyridine analogs. Res. Chem. Intermed. 2018, 44, 3549-3564. [CrossRef]

126. Hugas, M.; Garriga, M.; Pascual, M.; Aymerich, M.T.; Monfort, J.M. Enhancement of sakacin K activity against Listeria monocytogenes in fermented sausages with pepper or manganese as ingredients. Food Microbiol. 2002, 19, 519-528. [CrossRef]

127. Masatcioğlu, T.M.; Avşar, Y.K. Effects of flavorings, storage conditions, and storage time on survival of Staphylococcus aureus in Sürk cheese. J. Food Prot. 2005, 68, 1487-1491. [CrossRef] [PubMed]

128. Martínez, L.; Cilla, I.; Antonio Beltrán, J.; Roncalés, P. Effect of Capsicum annuum (red sweet and cayenne) and Piper nigrum (black and white) pepper powders on the shelf life of fresh pork sausages packaged in modified atmosphere. J. Food Sci. 2006, 71, 48-53. [CrossRef]

129. Krumov, K.; Ivanov, G.; Slavchev, A.; Nenov, N. Improving the processed cheese quality by the addition of natural spice extracts. Adv. J. Food Sci. Technol. 2010, 2, 335-339.

130. Agbabiaka, L.A.; Kuforiji, O.A.; Ndumnigwe, O.E. Storage and microbial evaluation of black pepper pre-treated oven-dried moon fish (Citharinus citharus Geoffery Saint-Hilaire 1809). J. Aquac. Res. Dev. 2016, 7. [CrossRef] 
131. Martínez, L.; Cilla, I.; Beltrán, J.A.; Roncalés, P. Effect of illumination on the display life of fresh pork sausages packaged in modified atmosphere. Influence of the addition of rosemary, ascorbic acid and black pepper. Meat Sci. 2007, 75, 443-450. [CrossRef] [PubMed]

132. Kapoor, I.P.S.; Singh, B.; Singh, S.; Singh, G. Essential oil and oleoresins of black pepper as natural food preservatives for orange juice. J. Food Process. Preserv. 2014, 38, 146-152. [CrossRef]

133. Zhang, J.; Wang, Y.; Pan, D.-D.; Cao, J.-X.; Shao, X.-F.; Chen, Y.-J.; Sun, Y.-Y.; Ou, C.-R. Effect of black pepper essential oil on the quality of fresh pork during storage. Meat Sci. 2016, 117, 130-136. [CrossRef] [PubMed]

134. Alencar Filho, E.B.; Castro Silva, J.W. A quantitative structure-activity relationships (QSAR) study of piperine based derivatives with leishmanicidal activity. Electron. J. Chem. 2017, 9, 43-49. [CrossRef]

135. Kapil, A. Piperine: A potent inhibitor of Leishmania donovani promastigotes in vitro. Planta Med. 1993, 59, 474. [CrossRef] [PubMed]

136. Ferreira, C.; Soares, D.C.; Barreto-Junior, C.B.; Nascimento, M.T.; Freire-de-Lima, L.; Delorenzi, J.C.; Lima, M.E.F.; Atella, G.C.; Folly, E.; Carvalho, T.M.U.; et al. Leishmanicidal effects of piperine, its derivatives, and analogues on Leishmania amazonensis. Phytochemistry 2011, 72, 2155-2164. [CrossRef] [PubMed]

137. Ribeiro, T.S.; Freire-de-Lima, L.; Previato, J.O.; Mendonça-Previato, L.; Heise, N.; de Lima, M.E.F. Toxic effects of natural piperine and its derivatives on epimastigotes and amastigotes of Trypanosoma cruzi. Bioorg. Med. Chem. Lett. 2004, 14, 3555-3558. [CrossRef] [PubMed]

138. Badmaev, V.; Majeed, M.; Prakash, L. Piperine derived from black pepper increases the plasma levels of coenzyme Q10 following oral supplementation. J. Nutr. Biochem. 2000, 11, 109-113. [CrossRef]

139. Balkrishna, B.; Yogesh, P.V. Influence of co-administration of piperine on pharmacokinetic profile of ciprofloxacin. Indian Drugs 2002, 39, 166-168.

140. Barve, K.; Ruparel, K. Effect of bioenhancers on amoxicillin bioavailability. ADMET DMPK 2015, 3, 45-50. [CrossRef]

141. Basu, S.; Jana, S.; Patel, V.B.; Patel, H. Effects of piperine, cinnamic acid and gallic acid on rosuvastatin pharmacokinetics in rats. Phytother. Res. 2013, 27, 1548-1556. [CrossRef] [PubMed]

142. Boddupalli, B.M.; Anisetti, R.N.; Ramani, R.; Malothu, N. Enhanced pharmacokinetics of omeprazole when formulated as gastroretentive microspheres along with piperine. Asian Pac. J. Trop. Dis. 2014, 4, S129-S133. [CrossRef]

143. Chen, X.Y.; Yang, G.H.; Li, C.L.; Yu, X.T.; Wang, X.F.; Zheng, Y.F.; Xie, J.H.; Lai, X.P.; Su, Z.R.; Liang, Y.Z.; et al. Pharmacokinetic interaction between magnolol and piperine in rats. Trop. J. Pharm. Res. 2016, 15, 631-638. [CrossRef]

144. Janakiraman, K.; Manavalan, R. Studies on effect of piperine on oral bioavailability of ampicillin and norfloxacin. Afr. J. Tradit. Complement. Altern. Med. 2008, 5, 257-262. [CrossRef] [PubMed]

145. Bano, G.; Raina, R.K.; Zutshi, U.; Bedi, K.L.; Johri, R.K.; Sharma, S.C. Effect of piperine on bioavailability and pharmacokinetics of propranolol and theophylline in healthy volunteers. Eur. J. Clin. Pharmacol. 1991, 41, 615-617. [CrossRef] [PubMed]

146. Di Pierro, F.; Settembre, R. Safety and efficacy of an add-on therapy with curcumin phytosome and piperine and/or lipoic acid in subjects with a diagnosis of peripheral neuropathy treated with dexibuprofen. J. Pain Res. 2013, 6, 497-503. [CrossRef] [PubMed]

147. Rezaee, M.M.; Kazemi, S.; Kazemi, M.T.; Gharooee, S.; Yazdani, E.; Gharooee, H.; Shiran, M.R.; Moghadamnia, A.A. The effect of piperine on midazolam plasma concentration in healthy volunteers, a research on the CYP3A-involving metabolism. DARU J. Pharm. Sci. 2014, 22, 8. [CrossRef]

148. Kasibhatta, R.; Naidu, M.U.R. Influence of piperine on the pharmacokinetics of nevirapine under fasting conditions: A randomised, crossover, placebo-controlled study. Drugs R D 2007, 8, 383-391. [CrossRef]

149. Atal, C.K.; Zutshi, U.; Rao, P.G. Scientific evidence on the role of Ayurvedic herbals on bioavailability of drug. J. Ethnopharmacol. 1981, 4, 229-232. [CrossRef]

150. Hussaarts, K.G.A.M.; Hurkmans, D.P.; Oomen-De Hoop, E.; van Harten, L.J.; Berghuis, S.; van Alphen, R.J.; Spierings, L.E.A.; van Rossum-Schornagel, Q.C.; Vastbinder, M.B.; van Schaik, R.H.N.; et al. Impact of curcumin (with or without piperine) on the pharmacokinetics of tamoxifen. Cancers 2019, 11, 403. [CrossRef]

151. Bano, G.; Amla, V.; Raina, R.K.; Zutshi, U.; Chopra, C.L. The effect of piperine on pharmacokinetics of phenytoin in healthy volunteers. Planta Med. 1987, 53, 568-569. [CrossRef] [PubMed]

152. Velpandian, T.; Jasuja, R.; Bhardwaj, R.K.; Jaiswal, J.; Gupta, S.K. Piperine in food: Interference in the pharmacokinetics of phenytoin. Eur. J. Drug Metab. Pharmacokinet. 2001, 26, 241-247. [CrossRef] [PubMed] 
153. Pattanaik, S.; Hota, D.; Prabhakar, S.; Kharbanda, P.; Pandhi, P. Effect of piperine on the steady-state pharmacokinetics of phenytoin in patients with epilepsy. Phytother. Res. 2006, 20, 683-686. [CrossRef] [PubMed]

154. Vora, A.; Patel, S.; Patel, K. Role of Risorine in the treatment of drug susceptible pulmonary tuberculosis: A pilot study. J. Assoc. Physicians India 2016, 64, 20-24. [PubMed]

155. Patel, N.; Jagannath, K.; Vora, A.; Patel, M.; Patel, A. A randomized, controlled, phase III clinical trial to evaluate the efficacy and tolerability of Risorine with conventional rifampicin in the treatment of newly diagnosed pulmonary tuberculosis patients. J. Assoc. Physicians India 2017, 65, 48-54. [PubMed]

156. Shoba, G.; Joy, D.; Joseph, T.; Majeed, M.; Rajendran, R.; Srinivas, P.S. Influence of piperine on the pharmacokinetics of curcumin in animals and human volunteers. Planta Med. 1998, 64, 353-356. [CrossRef] [PubMed]

157. Antony, B.; Merina, B.; Iyer, V.S.; Judy, N.; Lennertz, K.; Joyal, S. a pilot cross-over study to evaluate human oral bioavailability of $\mathrm{BCM}-95^{\circledR} \mathrm{CG}$ (Biocurcumax ${ }^{\mathrm{TM}}$ ), a novel bioenhanced preparation of curcumin. Indian J. Pharm. Sci. 2008, 70, 445-449. [CrossRef] [PubMed]

158. Badmaev, V.; Majeed, M.; Norkus, E. Piperine, an alkaloid derived from black pepper increases serum response of beta-carotene during 14-days of oral beta-carotene supplementation. Nutr. Res. 1999, 19, 381-388. [CrossRef]

159. Cherniakov, I.; Izgelov, D.; Barasch, D.; Davidson, E.; Domb, A.J.; Hoffman, A. Piperine-pro-nanolipospheres as a novel oral delivery system of cannabinoids: Pharmacokinetic evaluation in healthy volunteers in comparison to buccal spray administration. J. Control. Release 2017, 266, 1-7. [CrossRef] [PubMed]

160. Di, X.; Wang, X.; Di, X.; Liu, Y. Effect of piperine on the bioavailability and pharmacokinetics of emodin in rats. J. Pharm. Biomed. Anal. 2015, 115, 144-149. [CrossRef] [PubMed]

161. Feng, X.; Liu, Y.; Wang, X.; Di, X. Effects of piperine on the intestinal permeability and pharmacokinetics of linarin in rats. Molecules 2014, 19, 5624-5633. [CrossRef]

162. Hiwale, A.R.; Dhuley, J.N.; Naik, S.R. Effect of co-administration of piperine on pharmacokinetics of $\beta$-lactam antibiotics in rats. Indian J. Exp. Biol. 2002, 40, 277-281. [PubMed]

163. Jin, M.-J.; Han, H.-K. Effect of piperine, a major component of black pepper, on the intestinal absorption of fexofenadine and its implication on food-drug interaction. J. Food Sci. 2010, 75, H93-H96. [CrossRef] [PubMed]

164. Jin, Z.-H.; Qiu, W.; Liu, H.; Jiang, X.-H.; Wang, L. Enhancement of oral bioavailability and immune response of Ginsenoside Rh2 by co-administration with piperine. Chin. J. Nat. Med. 2018, 16, 143-149. [CrossRef]

165. Lambert, J.D.; Hong, J.; Kim, D.H.; Mishin, V.M.; Yang, C.S. Piperine enhances the bioavailability of the tea polyphenol (-)-epigallocatechin-3-gallate in mice. J. Nutr. 2004, 134, 1948-1952. [CrossRef] [PubMed]

166. Liang, Y.Z.; Chen, H.M.; Su, Z.Q.; Hou, S.Z.; Chen, X.Y.; Zheng, Y.F.; Li, Y.C.; Lin, J.; Zhan, J.Y.X.; Su, Z.R.; et al. White pepper and piperine have different effects on pharmacokinetics of puerarin in rats. Evid. Based Complement. Altern. Med. 2014, 2014, 796890. [CrossRef] [PubMed]

167. Mujumdar, A.M.; Dhuley, J.N.; Deshmukh, V.K.; Naik, S.R. Effect of piperine on bioavailability of oxyphenylbutazone in rats. Indian Drugs 1999, 36, 123-126.

168. Qiang, F.; Kang, K.-W.; Han, H.-K. Repeated dosing of piperine induced gene expression of P-glycoprotein via stimulated pregnane-X-receptor activity and altered pharmacokinetics of diltiazem in rats. Biopharm. Drug Dispos. 2012, 33, 446-454. [CrossRef] [PubMed]

169. Bhardwaj, R.K.; Glaeser, H.; Becquemont, L.; Klotz, U.; Gupta, S.K.; Fromm, M.F. Piperine, a major constituent of black pepper, inhibits human P-glycoprotein and CYP3A4. J. Pharmacol. Exp. Ther. 2002, 302, 645-650. [CrossRef]

170. Jensen-Jarolim, E.; Gajdzik, L.; Haberl, I.; Kraft, D.; Scheiner, O.; Graf, J. Hot spices influence permeability of human intestinal epithelial monolayers. J. Nutr. 1998, 128, 577-581. [CrossRef]

171. Han, Y.; Chin Tan, T.M.; Lim, L.Y. In vitro and in vivo evaluation of the effects of piperine on P-gp function and expression. Toxicol. Appl. Pharmacol. 2008, 230, 283-289. [CrossRef] [PubMed]

172. Makhov, P.; Golovine, K.; Canter, D.; Kutikov, A.; Simhan, J.; Corlew, M.M.; Uzzo, R.G.; Kolenko, V.M. Co-administration of piperine and docetaxel results in improved anti-tumor efficacy via inhibition of CYP3A4 activity. Prostate 2012, 72, 661-667. [CrossRef] [PubMed]

173. Alhumayyd, M.S.; Bukhari, I.A.; Almotrefi, A.A. Effect of piperine, a major component of black pepper, on the pharmacokinetics of domperidone in rats. J. Physiol. Pharmacol. 2014, 65, 785-789. [PubMed] 
174. Pattanaik, S.; Hota, D.; Prabhakar, S.; Kharbanda, P.; Pandhi, P. Pharmacokinetic interaction of single dose of piperine with steady-state carbamazepine in epilepsy patients. Phytother. Res. 2009, 23, 1281-1286. [CrossRef] [PubMed]

175. Bedada, S.K.; Appani, R.; Boga, P.K. Effect of piperine on the metabolism and pharmacokinetics of carbamazepine in healthy volunteers. Drug Res. 2017, 67, 46-51. [CrossRef] [PubMed]

176. Wightman, E.L.; Reay, J.L.; Haskell, C.F.; Williamson, G.; Dew, T.P.; Kennedy, D.O. Effects of resveratrol alone or in combination with piperine on cerebral blood flow parameters and cognitive performance in human subjects: A randomised, double-blind, placebo-controlled, cross-over investigation. Br. J. Nutr. 2014, 112, 203-213. [CrossRef]

177. Bedada, S.K.; Boga, P.K. Effect of piperine on CYP2E1 enzyme activity of chlorzoxazone in healthy volunteers. Xenobiotica 2017, 47, 1035-1041. [CrossRef] [PubMed]

178. Bedada, S.K.; Boga, P.K.; Kotakonda, H.K. Study on influence of piperine treatment on the pharmacokinetics of diclofenac in healthy volunteers. Xenobiotica 2017, 47, 127-132. [CrossRef] [PubMed]

179. Bedada, S.K.; Boga, P.K. The influence of piperine on the pharmacokinetics of fexofenadine, a P-glycoprotein substrate, in healthy volunteers. Eur. J. Clin. Pharmacol. 2017, 73, 343-349. [CrossRef] [PubMed]

180. Rofes, L.; Arreola, V.; Martin, A.; Clavé, P. Effect of oral piperine on the swallow response of patients with oropharyngeal dysphagia. J. Gastroenterol. 2014, 49, 1517-1523. [CrossRef]

181. Kaur, S.; Sharma, R.; Sarangal, V.; Kaur, N.; Prashar, P. Evaluation of anti-inflammatory effects of systemically administered curcumin lycopene and piperine as an adjunct to scaling and root planing: A clinical study. Ayu 2018, 38, 117-121. [CrossRef] [PubMed]

182. Shafiee, A.; Hoormand, M.; Shahidi-Dadras, M.; Abadi, A. The effect of topical piperine combined with narrowband UVB on vitiligo treatment: A clinical trial study. Phytother. Res. 2018, 32, 1812-1817. [CrossRef] [PubMed]

183. Mihăilă, B.; Dinică, R.; Tatu, A.; Buzia, O. New insights in vitiligo treatments using bioactive compounds from Piper nigrum. Exp. Ther. Med. 2018, 17, 1039-1044. [CrossRef] [PubMed]

184. O'Connor, A.; Corbin, K.D.; Nieman, D.C.; Swick, A.G. A randomized, controlled trial to assess short-term black pepper consumption on 24-hour energy expenditure and substrate utilization. Funct. Foods Health Dis. 2013, 3, 377-388. [CrossRef]

185. Panahi, Y.; Ghanei, M.; Hajhashemi, A.; Sahebkar, A. Effects of curcuminoids-piperine combination on systemic oxidative stress, clinical symptoms and quality of life in subjects with chronic pulmonary complications due to sulfur mustard: A randomized controlled trial. J. Diet. Suppl. 2016, 13, 93-105. [CrossRef] [PubMed]

186. Panahi, Y.; Hosseini, M.S.; Khalili, N.; Naimi, E.; Majeed, M.; Sahebkar, A. Antioxidant and anti-inflammatory effects of curcuminoid-piperine combination in subjects with metabolic syndrome: A randomized controlled trial and an updated meta-analysis. Clin. Nutr. 2015, 34, 1101-1108. [CrossRef] [PubMed]

187. Donata, S.R.; Kesavan, M., Sr.; Austin, K.S.; Rajagopalan, K.; Kuttan, R. Clinical trial of certain ayurvedic medicines indicated in vitiligo. Anc. Sci. Life 1990, 9, 202-206.

188. Rondanelli, M.; Opizzi, A.; Perna, S.; Faliva, M.; Solerte, S.B.; Fioravanti, M.; Klersy, C.; Edda, C.; Maddalena, P.; Luciano, S.; et al. Acute effect on satiety, resting energy expenditure, respiratory quotient, glucagon-like peptide-1, free fatty acids, and glycerol following consumption of a combination of bioactive food ingredients in overweight subjects. J. Am. Coll. Nutr. 2013, 32, 41-49. [CrossRef]

189. Myers, B.M.; Smith, J.L.; Graham, D.Y. Effect of red pepper and black pepper on the stomach. Am. J. Gastroenterol. 1987, 82, 211-214. [PubMed]

190. Vazquez-Olivencia, W.; Shah, P.; Pitchumoni, C.S. The effect of red and black pepper on orocecal transit time. J. Am. Coll. Nutr. 1992, 11, 228-231.

191. Rose, J.E.; Behm, F.M. Inhalation of vapor from black pepper extract reduces smoking withdrawal symptoms. Drug Alcohol Depend. 1994, 34, 225-229. [CrossRef]

192. Ebihara, T.; Ebihara, S.; Maruyama, M.; Kobayashi, M.; Itou, A.; Arai, H.; Sasaki, H. A randomized trial of olfactory stimulation using black pepper oil in older people with swallowing dysfunction. J. Am. Geriatr. Soc. 2006, 54, 1401-1406. [CrossRef] [PubMed]

193. Munakata, M.; Kobayashi, K.; Niisato-Nezu, J.; Tanaka, S.; Kakisaka, Y.; Ebihara, T.; Ebihara, S.; Haginoya, K.; Tsuchiya, S.; Onuma, A. Olfactory stimulation using black pepper oil facilitates oral feeding in pediatric patients receiving long-term enteral nutrition. Tohoku J. Exp. Med. 2008, 214, 327-332. [CrossRef] [PubMed] 
194. Gregersen, N.T.; Belza, A.; Jensen, M.G.; Ritz, C.; Bitz, C.; Hels, O.; Frandsen, E.; Mela, D.J.; Astrup, A. Acute effects of mustard, horseradish, black pepper and ginger on energy expenditure, appetite, ad libitum energy intake and energy balance in human subjects. Br. J. Nutr. 2013, 109, 556-563. [CrossRef] [PubMed]

195. Lindheimer, J.B.; Loy, B.D.; O'Connor, P.J. Short-term effects of black pepper (Piper nigrum) and rosemary (Rosmarinus officinalis and Rosmarinus eriocalyx) on sustained attention and on energy and fatigue mood states in young adults with low energy. J. Med. Food 2013, 16, 765-771. [CrossRef] [PubMed] 